\title{
Effect of Steel Galvanization on the Microstructure and Mechanical Performances of Planar Magnetic Pulse Welds of Aluminum and Steel
}

\begin{abstract}
M.-N. AVETTAND-FÈNOËL, C. KHALIL, R. TAILLARD, and G. RACINEUX
For the first time, planar joints between pure aluminum and galvanized or uncoated DP450 steel joints have been developed via magnetic pulse welding. Both present a wavy interface. The microstructure of the interfacial zone differs according to the joint. With uncoated steel, the interface is composed of discrete 2.5- $\mu$ m-thick $\mathrm{FeAl}_{3}$ intermetallic compounds and $\mathrm{Fe}$ penetration lamellae, whereas the interface of the pure Al-galvanized steel joint is bilayered and composed of a $10-\mathrm{nm}$-thick $(\mathrm{Al})_{\mathrm{Zn}}$ solid solution and a few micrometers thick aggregate of $\mathrm{Al}$ - and $\mathrm{Zn}$-based grains, arranged from the $\mathrm{Al}$ side to the $\mathrm{Zn}$ coating. Even if the nature of the interfacial zone differs with or without the steel coating, both welds present rather similar maximum tensile forces and ductility in shear lap testing.
\end{abstract}

https://doi.org/10.1007/s11661-018-4651-y

(c) The Minerals, Metals \& Materials Society and ASM International 2018

\section{INTRODUCTION}

FOR lightening and subsequent energy cost purposes, aluminum alloy and steel joining has gained increasing interest, particularly in the automotive and railway industry. ${ }^{[1]}$ Because of its light weight and good formability, aluminum alloy has been tested to replace, or at least to be joined to, stiff, strong, and tough steel. However, aluminum to steel dissimilar joining remains a challenge because of the difference in their melting points $\left[933(660)\right.$ vs $\left.1836 \mathrm{~K}\left(1563{ }^{\circ} \mathrm{C}\right)\right]$, specific heats (897 vs $450 \mathrm{~J} \mathrm{~kg}^{-1} \mathrm{~K}^{-1}$ ), thermal conductivities (238 vs $\left.75 \mathrm{~W} \mathrm{~m}^{-1} \mathrm{~K}^{-1}\right)$, thermal expansion coefficients $\left(23.8 \times 10^{-6}\right.$ vs $\left.12.3 \times 10^{-6} \mathrm{~K}^{-1}\right)$, elasticity moduli (72000 vs $210000 \mathrm{MPa})$, and tensile strengths (80 vs 270 to $410 \mathrm{MPa}$ ) (from References 2 and 3), which causes voids, residual stresses, and distortion. The high chemical affinity of these materials ${ }^{[4]}$ is another key difficulty for welding because it causes the formation of intermetallic compounds (IMCs). ${ }^{[2,5]}$

Many investigations report welding of $\mathrm{Al}$ to galvanized or bare steel, for instance, (1) in the liquid state through various processes, such as metal arc joining, ${ }^{[6-14]}$ cold metal transfer, ${ }^{[15,16]}$ resistance spot

M.-N. AVETTAND-FÈNOËL and R. TAILLARD are with the Unité Matériaux Et Transformations (UMET), UMR CNRS 8207, Université Lille 1, 59655 Villeneuve d'Ascq, France. Contact email: marie-noelle.avettand-fenoel@univ-lille1.fr C. KHALIL and G. RACINEUX are with the Institut de Recherche en Génie Civil et Mécanique, UMR CNRS 6183, Ecole Centrale de Nantes, 44321 Nantes, France.

Manuscript submitted July 18, 2017

Article published online May 11, 2018 welding, ${ }^{[17-25]}$ electric discharge bonding, ${ }^{[26]}$ electron beam welding, ${ }^{[27,28]}$ explosive welding, ${ }^{[29-31]}$ laser welding, ${ }^{[1-3,32-44]}$ laser ${ }^{[45-49]}$ or furnace brazing, ${ }^{[50,51]}$ or hybrid processes such as laser metal inert gas (MIG) welding, ${ }^{[52,53]}$ laser roll welding, ${ }^{[42]}$ and tungsten inert gas (TIG) welding plus brazing, ${ }^{[54,55]}$ and $(2)$ in a semi-solid state by friction stir brazing. ${ }^{[56,57]}$ However, in addition to the problems of distortion and solidification defects that occur, due to the good chemical affinity of $\mathrm{Al}$ and $\mathrm{Fe}$, these processes lead to the rapid formation of IMCs at the interface of both materials. Such precipitation is all the more favored in the liquid state (see Table IV in the appendix at the end of the paper). Even if the IMCs can ensure bonding between the base materials, their formation remains a common problem during dissimilar joining, especially if they are continuous and too thick. ${ }^{[58]}$ With these features, they can deteriorate the mechanical properties of the assembly because of their brittleness.

To limit the formation of IMCs during the joining of Al to steel and to improve the joint strength, various solutions have been proposed:

(1) Adjusting the process parameters to either limit the heat input at the $\mathrm{Al} / \mathrm{steel}^{\text {interface }} \mathrm{e}^{[3,36]}$ or reduce the welding time by preheating the steel. ${ }^{[5,35]}$

(2) Changing the chemical composition of the interface to either modify the nature of IMCs or reduce the diffusion kinetics. Such modifications, for instance, consist of a larger proportion of $\mathrm{Al}$ in a steel-pure $\mathrm{Al}$ laminate filler during resistance spot welding ${ }^{[24]}$ or of a $\mathrm{Si}^{[3,5,59,60]}$ or $\mathrm{Zn}$ addition in an $\mathrm{Al}$ filler metal. ${ }^{[45,60,61]}$ The $\mathrm{Zn}$ addition 
promotes the formation of an aggregate of $\mathrm{Fe}_{2} \mathrm{Al}_{5} \mathrm{Zn}_{x}, \mathrm{FeZn}_{10}$, and Al-rich amorphous particles, enhancing the joint mechanical resistance. ${ }^{[62]}$ The beneficial effects of a $15 \mathrm{wt}$ pct $\mathrm{Cu}^{[59,60,63]}$ or $0.1 \mathrm{wt}$ pct $\mathrm{Be}^{[3]}$ addition in liquid $\mathrm{Al}$ during steel aluminization have also been reported. A $\mathrm{Zn},{ }^{[56]} \mathrm{Ni},{ }^{[16]} \mathrm{Ag},{ }^{[27,64]} \mathrm{Al}, \mathrm{Al}-\mathrm{Mg}$, $\mathrm{Ni}-\mathrm{Zn}, \mathrm{Zn}-\mathrm{Al}$, or $\mathrm{Ag}-\mathrm{Zn}^{[3]}$ coating on steel also hampers the interdiffusion between $\mathrm{Fe}$ and $\mathrm{Al}$ during arc welding.

(3) Using solid-state welding processes. Some studies consider friction welding, ${ }^{[65-68]}$ friction stir welding, ${ }^{[58,69-88]}$ friction stir diffusion bonding, ${ }^{[89]}$ ultrasonic welding, ${ }^{[90]}$ roll bonding, ${ }^{[91-93]}$ diffusion bonding, ${ }^{[64,75,94-98]}$ or hybrid processes ${ }^{[5]}$ such as FSW assisted by diffusion bonding, ${ }^{[83]}$ by an electrical current, ${ }^{[99]}$ by gas tungsten arc welding, ${ }^{[100]}$ or by a laser. ${ }^{[101]}$

These solid-state welding processes require a significant heat input to ensure suitable steel plasticization or sufficient atomic mobility. However, such a condition can still entail the formation of IMCs, whose nature and distribution will depend on the process settings. ${ }^{[102]}$

Table IV illustrates some results from a non-exhaustive list of examples addressing the features of the IMCs that form during steel-Al welding in the liquid or solid state.

In addition to all of the previously cited joining processes, Table IV lists some semi-solid-state processes such as explosive welding ${ }^{[29-31]}$ and magnetic pulse welding (MPW). MPW is an environmentally friendly and repeatable process that is particularly recommended for joining dissimilar materials. Although it is not commonly used (Table IV), magnetic pulse welding (MPW) indeed leads to rather low peak temperatures for a very short time (a few microseconds) ${ }^{[103,104]}$ and thus to no significant heat-affected zone. ${ }^{[103-105]}$ MPW is based on high-speed electromagnetic forming at room temperature. This process can be applied to tubular or planar workpieces. ${ }^{[103,104,106]}$ The principle of MPW used with planar workpieces is thoroughly covered in previous works. ${ }^{[107,108]}$ With regard to the Al-steel system, various joints were obtained by MPW in tubular $^{[109-119]}$ and planar ${ }^{[105,107,108,120-123]}$ configurations. In the latter case, joining was supposed to consume much less energy than with tubes, ${ }^{[123]}$ which should limit the formation of IMCs. Moreover, among the few studies of the interface microstructure, ${ }^{[105,107-109,111-113,120]}$ only a few short investigations concern the case of planar joints ${ }^{[105,107,108,120,123]}$ and none consider the MPW joining of galvanized steel with aluminum.

To fill this gap, the current paper aims to investigate the effect of a galvanized steel coating at various length scales on the microstructure of the Al-steel interface in planar magnetic pulsed welds. The influence of the consecutive change of the interface microstructure on the mechanical properties of both kinds of joints is subsequently considered.

\section{EXPERIMENTAL PROCEDURE}

The base materials are 40-mm-wide coupons of AA1050 aluminum (90 mm long and $0.5 \mathrm{~mm}$ thick, hardness of $40 \mathrm{HV}_{0.05}$ ) and of either industrially hot-dip galvanized or uncoated cold-rolled DP450 steel (110 $\mathrm{mm}$ long and $1.17 \mathrm{~mm}$ thick, hardness of $\left.160 \mathrm{HV}_{0.05}\right)$. Their chemical compositions, supplied by the provider, are listed in Table I. Aluminum, which is the better electrical conductor, constitutes the flyer sheet, whereas steel, with a greater yield strength, is the target workpiece. An 8-mm-wide and 12-mm-long hump was deep drawn on the Al flyer sheet (Figure 1). The sheets were cleaned with acetone and stacked over a lap length of $50 \mathrm{~mm}$. They were finally joined by magnetic pulse welding with a discharge energy of $10 \mathrm{~kJ}$. The generator has a capacitance of $408 \mu \mathrm{F}$, an inductance of $100 \mathrm{nH}$, and a resistance of $14 \mathrm{~m} \Omega$. The $\mathrm{Cu}$ inductor (Figure 2) presents a 20-mm-long and 2.7-mm-thick active zone, a 44-nH inductance, and a $0.1-\mathrm{m} \Omega$ resistance. An insulating sheet with a thickness of $0.1 \mathrm{~mm}$ is inserted at the Al-inductor interface. The stand-off distance corresponds to the hump depth of $1.5 \mathrm{~mm}$.

The transverse cross sections of the joints were diamond polished to $1 \mu \mathrm{m}$ and characterized by light microscopy, scanning electron microscopy, and X-ray energy dispersive spectroscopy (EDX/SEM) with the secondary electron (SE) or back-scattering electron (BSE) mode.

For the (scanning) transmission electron microscopy ((S)TEM)/EDX) and electron diffraction investigations, thin foils were prepared using the focused ionic dual beam (FIB) technique. During cutting, the thin foil edge facing the ion beam was protected by a $3.5-\mu \mathrm{m}$-thick deposit of platinum. A 300-pA beam intensity was applied for final thinning.

X-ray diffractometry (XRD) was performed on the transverse cross section of the weld using a Bragg-Brentano configuration and a cobalt anticathode $\left[\lambda_{\mathrm{Co}}\right.$ $\left.\left(K_{\alpha 1}\right)=1.78901 \AA\right]$.

Vickers microhardness tests were performed under a $50 \mathrm{~g}$ load with a 15-second dwell time along the MPW joint in the transverse cross section.

Three to four tensile shear lap tests were finally performed on each kind of full weld along the length of the rectangular joint at a rate of $1 \mathrm{~mm} / \mathrm{min}$.

\section{RESULTS}

\section{A. Validation of the Process Settings}

The physical parameters of MPW are the impact velocity $\left(V_{\mathrm{i}}\right)$ and angle of incidence $(\beta)$. To obtain a sound weld, the first value should exceed $200 \mathrm{~m} / \mathrm{s}$, whereas the second setting that ensures the required progressive impact is an angle of incidence between $6 \mathrm{deg}$ and $30 \mathrm{deg} .{ }^{[124-126]}$ The controllable process parameters are the discharge energy and the coil and hump geometries and dimensions. A fully coupled 3D 


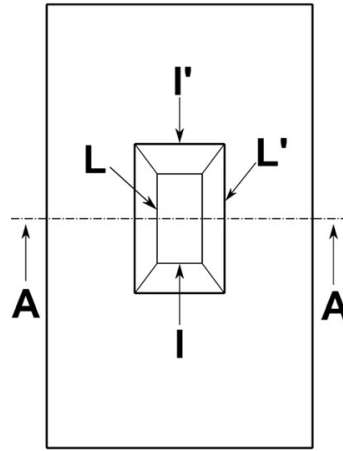

\begin{tabular}{|l|l|}
\hline$L(m m)$ & 12 \\
\hline$L^{\prime}(\mathrm{mm})$ & 27 \\
\hline$I(\mathrm{~mm})$ & 8 \\
\hline $\mathrm{I}^{\prime}(\mathrm{mm})$ & 14 \\
\hline $\mathrm{h}(\mathrm{mm})$ & 1,5 \\
\hline - & $26,6^{\circ}$ \\
\hline
\end{tabular}

Section A-A

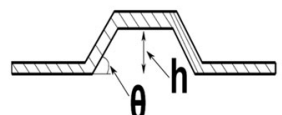

Fig. 1-Schematics and dimensions of the hump on the flyer plate.
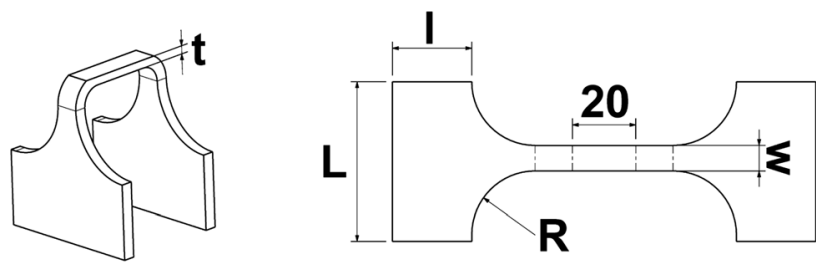

\begin{tabular}{|l|l|l|l|}
\hline$L(\mathrm{~mm})$ & $I(\mathrm{~mm})$ & $R(\mathrm{~mm})$ & $W(\mathrm{~mm})$ \\
\hline 25 & 25 & 19 & 8 \\
\hline
\end{tabular}

Fig. 2-Schematics of the $\mathrm{Cu}$ inductor: three-dimensional and unfolded two-dimensional views with dimensions. The thickness of the inductor active zone is $2.7 \mathrm{~mm}$.

numerical simulation was performed using the LS-Dyna code in order to confirm the suitability of the physical parameters for welding. LS-Dyna is a dynamic code that uses a coupled FEM (finite element method)-BEM (binary element method) numerical scheme for coupling electromagnetic results with mechanical and thermal solutions. ${ }^{[127]}$

As displayed in Figure 3, the simulation model allows drawing a velocity profile at the moment of impact between the flyer (i.e., Al 1050) and the parent metal (i.e., DP450 steel). Once the required impact velocity and angle are obtained, the process parameters are experimentally validated.

The Johnson-Cook law ${ }^{[128]}$ was used for the dynamic behavior of Al 1050 (Eq. [1]):

$$
\sigma_{\mathrm{eq}}=\left[A+B p^{n}\right] \times\left[1+C \ln \left(\frac{\dot{p}}{\dot{p}_{0}}\right)\right]\left[1-\left(T^{*}\right)^{m}\right],
$$

where $\sigma_{\mathrm{eq}}$ is the equivalent flow stress; $A$ is the yield strength coefficient, equal to $25 \mathrm{GPa}$; $B$ is the hardening modulus, equal to $25 \mathrm{GPa}$; $\mathrm{C}$ is a constant, equal to $8 ; p$ is the plastic strain; $\dot{p}$ is the plastic strain rate; $\dot{p}_{0}$ is the reference plastic strain rate, equal to $1 \mathrm{~s}^{-1} ; n$ and $\mathrm{m}$ are constants, equal to 19 and 1 , respectively ${ }^{[128]}$; and 


$$
T^{*}=\left(\frac{T-T_{0}}{T_{m}-T_{0}}\right),
$$

where $T_{\mathrm{m}}$ is the melting temperature, equal to $918.15 \mathrm{~K}$, and $T_{0}$ is the room temperature. Applying a discharge energy of $10 \mathrm{~kJ}$, which corresponds to a discharge voltage of $7 \mathrm{kV}$, the peak of the sinusoidal discharge current in the simulation is $277 \mathrm{kA}$ and the frequency is close to $20.65 \mathrm{kHz}$. The simulation results sufficiently agree with the measured values, which are $280 \mathrm{kA}$ and $20.4 \mathrm{kHz}$, respectively. The error is thus approximately 1.1 pct.

According to the simulation, the impact occurs after approximately $9.5 \mu$ s which corresponds to the time at which the current reaches its peak value. This estimation is again verified by experiments. ${ }^{[129,130]}$ The nearly $514 \mathrm{~m} / \mathrm{s}$ impact velocity and the nearly 9 deg impact angle are in the

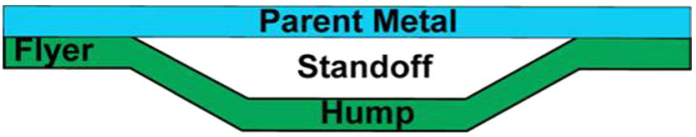

(a)

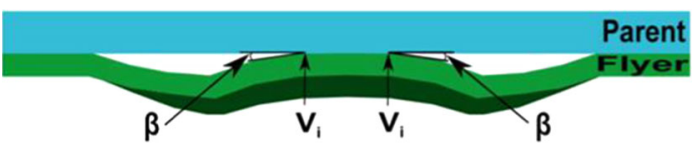

(b)

Fig. 3-Schematics of the principle of magnetic pulse welding: (a) prior to discharge and $(b)$ at the moment of impact.
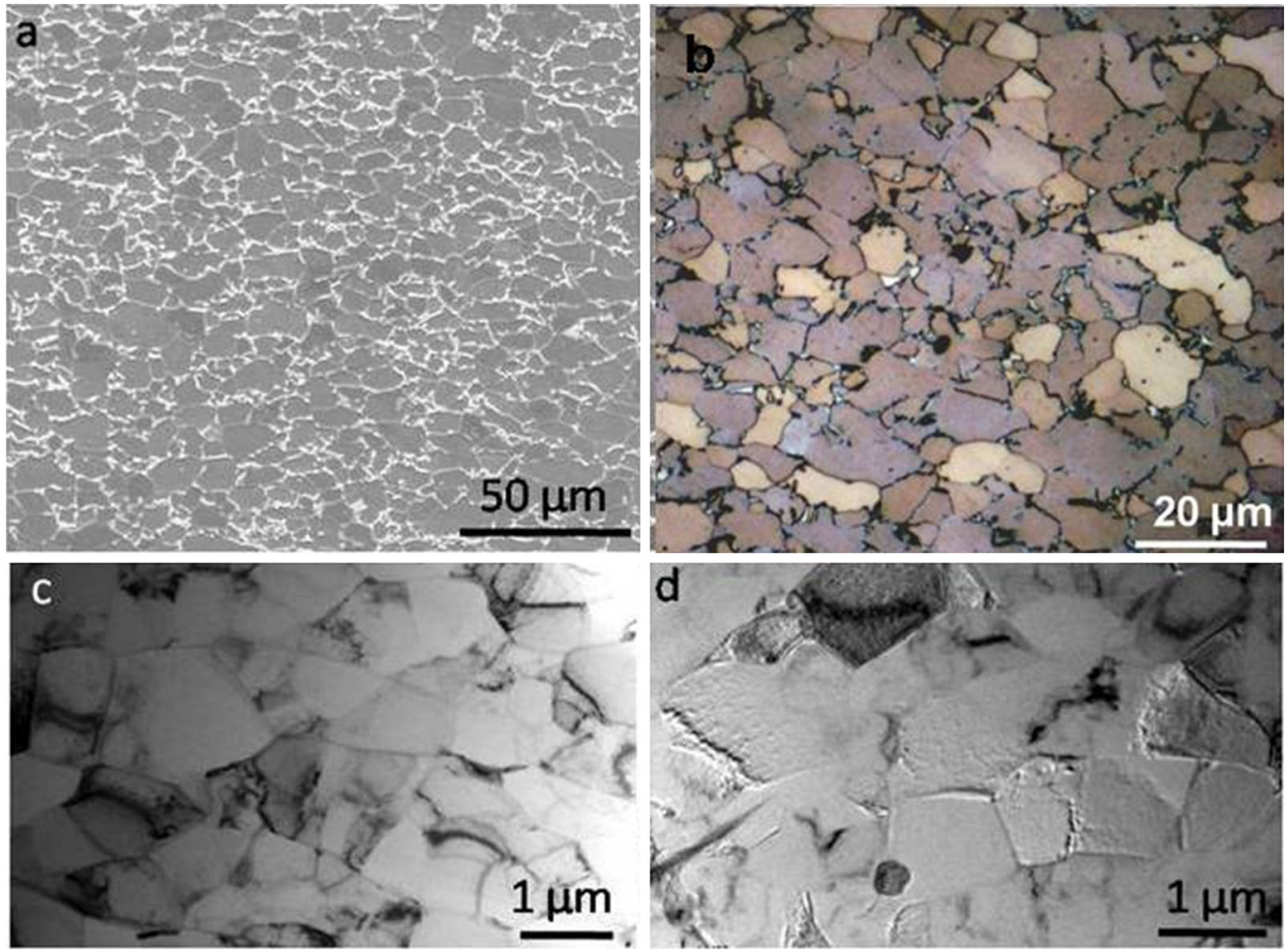

Fig. 4-Transverse cross section of the DP450 steel after either 2 pct nital etching (SE/SEM) ( $a$ ) or Marder-Benscoter etching $(b)$, and aluminum structure (TEM) $(c, d)$. In micrograph b, austenite is white, ferrite is off-white, blocky martensite is black, and pearlite is black and white. 


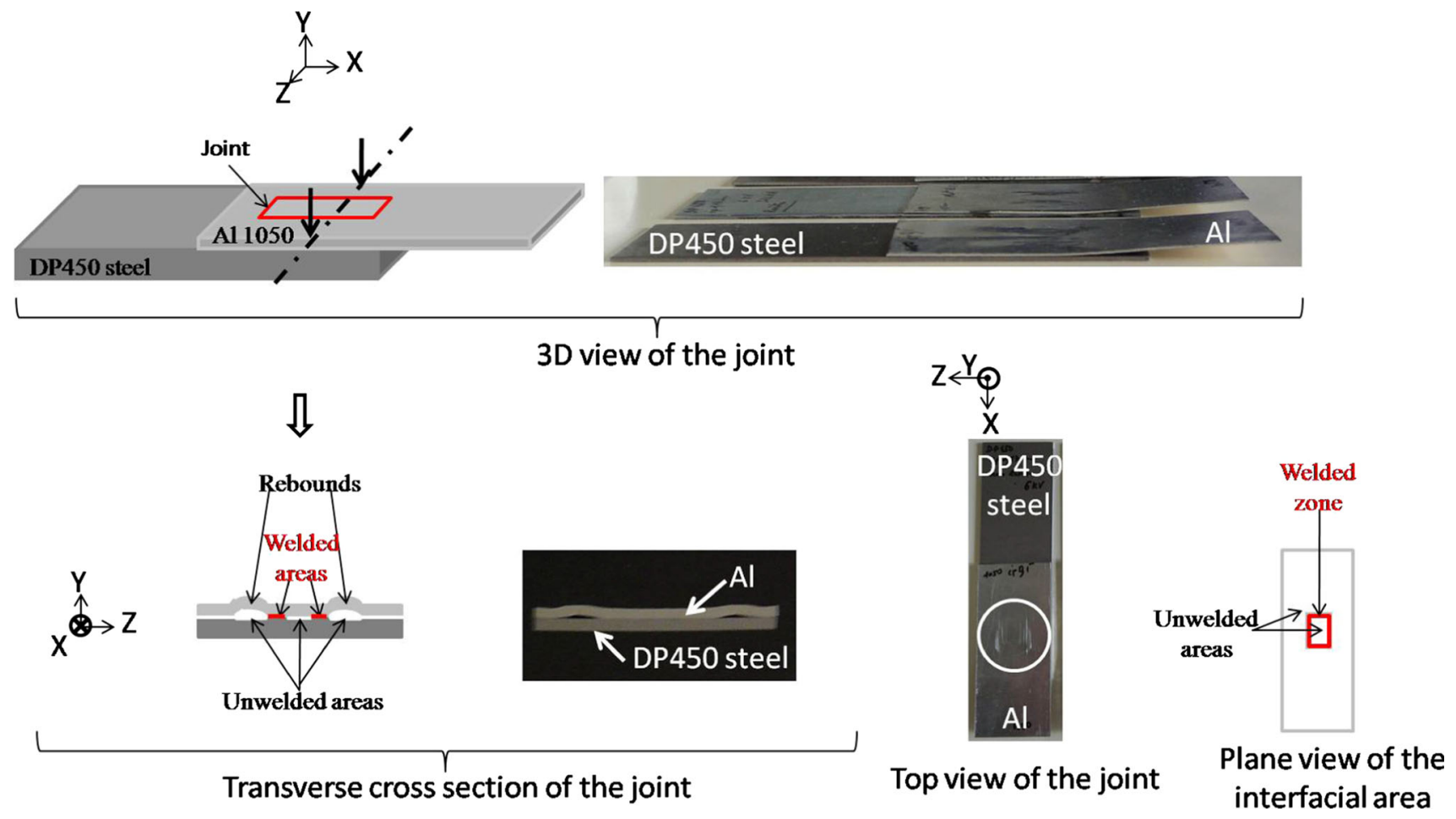

Fig. 6-Various views of the magnetic pulse joint. The white circle in the top view of the joint encircles the elliptical weld trace that corresponds to the border of the hump.
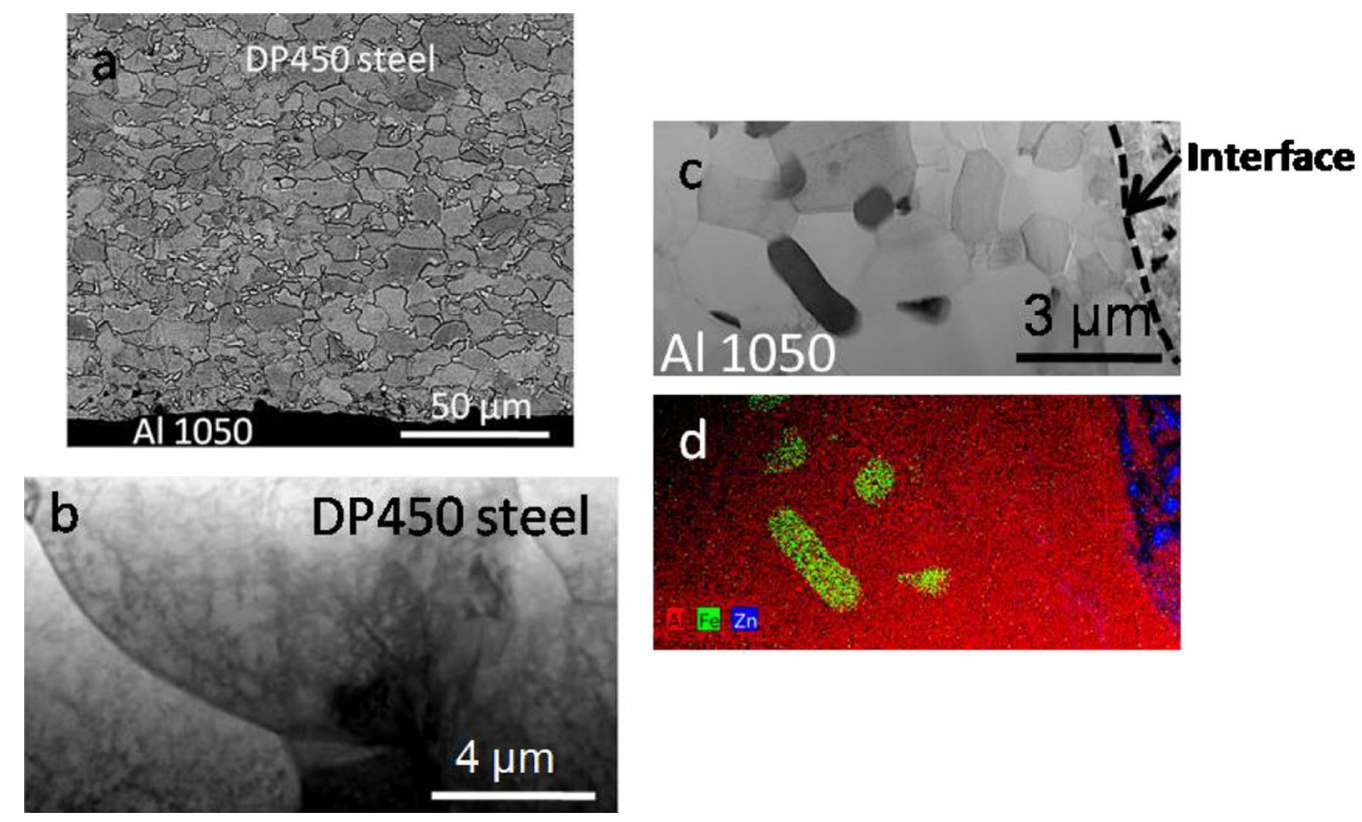

Fig. 7-Al 1050-coated DP450 steel joint: (a) Transverse cross section of the joint (BSE/SEM). The steel was etched with 2 pct nital. (b) The steel grains in close contact with the interface contain dislocations cells (TEM). ( $c$ and $d$ ) Al grains near the interface and X-ray Al-K $\alpha$ (red), $\mathrm{Fe}-\mathrm{K} \alpha$ (green), and $\mathrm{Zn}-\mathrm{K} \alpha$ (blue) composite map (EDX/STEM) (Color figure online).

\section{Magnetic Pulsed Joints}

1. Macroscopic view of the joint

A schematic of the MPW joint, as well as its three-dimensional view, transverse section, and global top overview, is displayed in Figure 6. It is worth noting that the $\mathrm{Al}$ sheet is bent after magnetic pulse welding as suggested by the $3 \mathrm{D}$ view. In addition, both sheets are welded along an elliptical shaped ribbon with a $1 \mathrm{~mm}$ average width. This ribbon follows the inner border of the hump. As schematized in Figure 6, in the area 
encircled by the ribbon, both sheets are not bonded because of the rebound. Such a lack of joining is the rule for magnetic pulsed welds as reported in the literature. ${ }^{[107,133]}$

\section{Microstructure of the joint}

a. Vicinity of the weld interface. Figure 7(a) shows that at the bonded interface, the steel microstructure is not modified at the mesoscopic scale by magnetic pulse welding. This result is consistent with some previous studies. $^{[104,120]}$ Otherwise, the $\mathrm{Al}$ grains are rather equiaxed with a size close to $1 \mu \mathrm{m}$. In addition, the steel grains contain dislocation cells close to $0.7 \mu \mathrm{m}$ in size, whereas the Al grains are dislocation free and contain some second phases composed of 70 at. pct Al, 25 at. pct $\mathrm{Fe}$, and 5 at. pct $\mathrm{Si}$ at first sight (Figures 7(b) and (d)). Such an uncommon chemical composition is very likely overestimated in Al due to the overly large extent of the X-ray source region. The presence of particles that are more enriched in $\mathrm{Fe}$ and $\mathrm{Si}$ is indeed the rule in raw Al 1050 alloys. ${ }^{[134]}$

In addition, regardless of the joint, i.e., with or without the galvanized layer, the interface has the same wavy shape, which results from the pulsed waves generated during welding (Figure 8). Figure 8 further displays the variability of the transition zone width which can extend up to $2 \mu \mathrm{m}$ in steel.

In relationship with the impact symmetry and the planar joint configuration, the slope of the waves is reversed from one side of the central unbonded zone to the opposite side.

b. Chemical nature of the joint interface. The X-ray diffractometry analysis of the interface shows the following:

(1) For the case of the uncoated steel, the $\mathrm{FeAl}_{3}$ compound is predominantly detected together with small amounts of the $\mathrm{Fe}_{2} \mathrm{Al}_{5}$ and $\mathrm{Fe}_{4} \mathrm{Al}_{13}$ phases (Figure 9(a)).

(2) For the joint with coated steel, some pure $\mathrm{Zn}$, $\mathrm{Fe}_{2} \mathrm{Al}_{5}, \mathrm{FeAl}_{3}$, and $\mathrm{Fe}_{4} \mathrm{Al}_{13}$ compounds are observed, which is very likely due to the presence of the inhibition layer in the galvanized layer (Figure 9(b)).

In addition, most of the small intensity peaks and those marked by question marks in Figure 9 may correspond either to cementite or to the $\mathrm{Al}_{x} \mathrm{Fe}_{y} \mathrm{Si}_{z}$ compounds observed in Figure 7.

The transverse cross sections of both joints were also investigated at the finer length scale of TEM.

In the case of the Al 1050-uncoated steel weld, some discrete intermetallic compounds with a maximum thickness of approximately $2.5 \mu \mathrm{m}$ are detected in the interfacial zone (Figure 10). In accordance with the XRD analyses (Figures 9(a) and (b)), their chemical composition determined by STEM/EDX is approximately 75 at. pet $\mathrm{Al}$ and 25 at. pct Fe, which corresponds to $\mathrm{FeAl}_{3}$ (Figure 11). At the interface, some harder Fe-rich convoluted lamellae are further detected within the softer Al part and inside the mixed zone (Figures 10 and 11). They are composed of grains that are nearly $100 \mathrm{~nm}$ in size which is approximately 100 times smaller than the grains of the base steel. These grains result either from the dynamic recrystallization of Fe during MPW or from recrystallization due to heating during thin foil preparation by FIB.

For the Al 1050-galvanized steel weld, it is worth noting the irregular thickness of the interfacial zone (Figure 12). In addition, going from steel to aluminum, the interfacial zone is composed of an inhibition layer, a zinc layer, and an $\mathrm{Al}+\mathrm{Zn}$ bi-phased layer (Figure 13). This observation agrees with the XRD results (Figure 9(b)) obtained at the mesoscopic scale. In the following, the $\mathrm{Al}+\mathrm{Zn}$ bi-phased layer will be called the extra layer because, contrary to the other layers, it does not take part in the original steel coating. The flatness of the galvanized interface between steel and $\mathrm{Zn}$ contrasts with the unevenness of the $\mathrm{Zn}$ /extra layer and extra layer/Al interfaces. In addition, two types of waviness that are differentiated by both their periodicity along the joint and their amplitude of oscillation can be noted along the zinc/extra layer and extra layer/Al interfaces. According to the location along the joint, the respective thicknesses of both the zinc and the extra layer may significantly change, but their total thickness remains less than $12 \mu \mathrm{m}$ (Figure 12). At the location of thin foil 2 , an 8 - $\mu$ m-thick extra layer composed of equiaxed grains with a diameter between 50 and $450 \mathrm{~nm}$ is formed (Figure 13). This extra layer can be thinner $(1 \mu \mathrm{m})$ (Figure 14), for instance at the constricted place marked by a white arrow in Figure 12. The $\mathrm{Zn}$ layer is approximately 2.3 and $7 \mu \mathrm{m}$ thick in the first (thin foil 2) and second (thin foil 3) cases, respectively. Compared to the $[6$ to $10 \mu \mathrm{m}$ ] initial thickness of the $\mathrm{Zn}$ coating, the

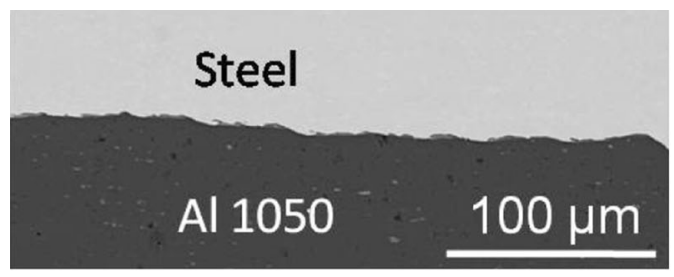

(a)

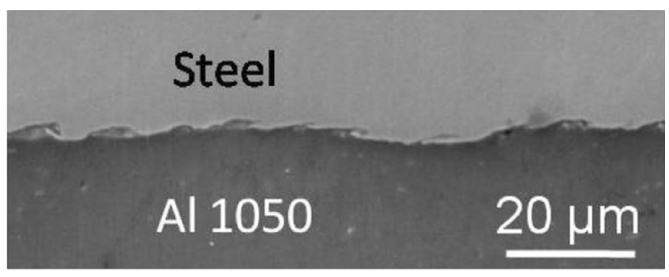

(b)

Fig. 8-Aspect of the Al 1050-DP450 steel interface (a): BSE/SEM, (b): SE/SEM magnified view of figure (a) (Y,Z plane). 


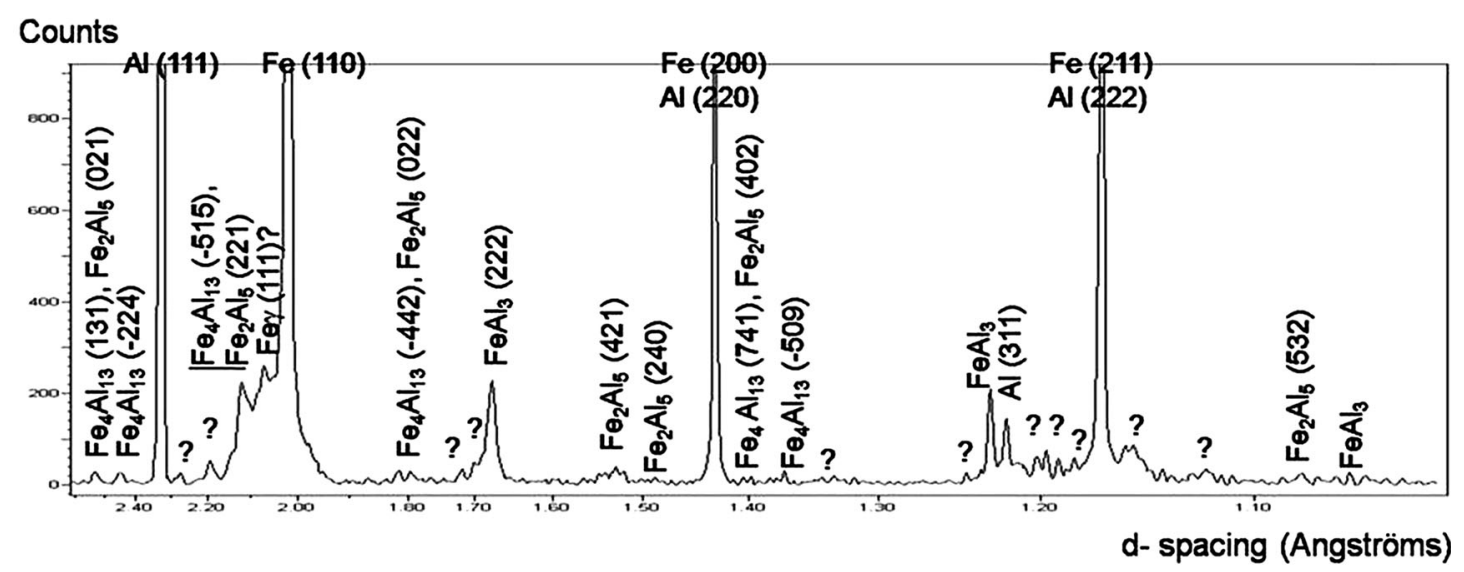

(a)

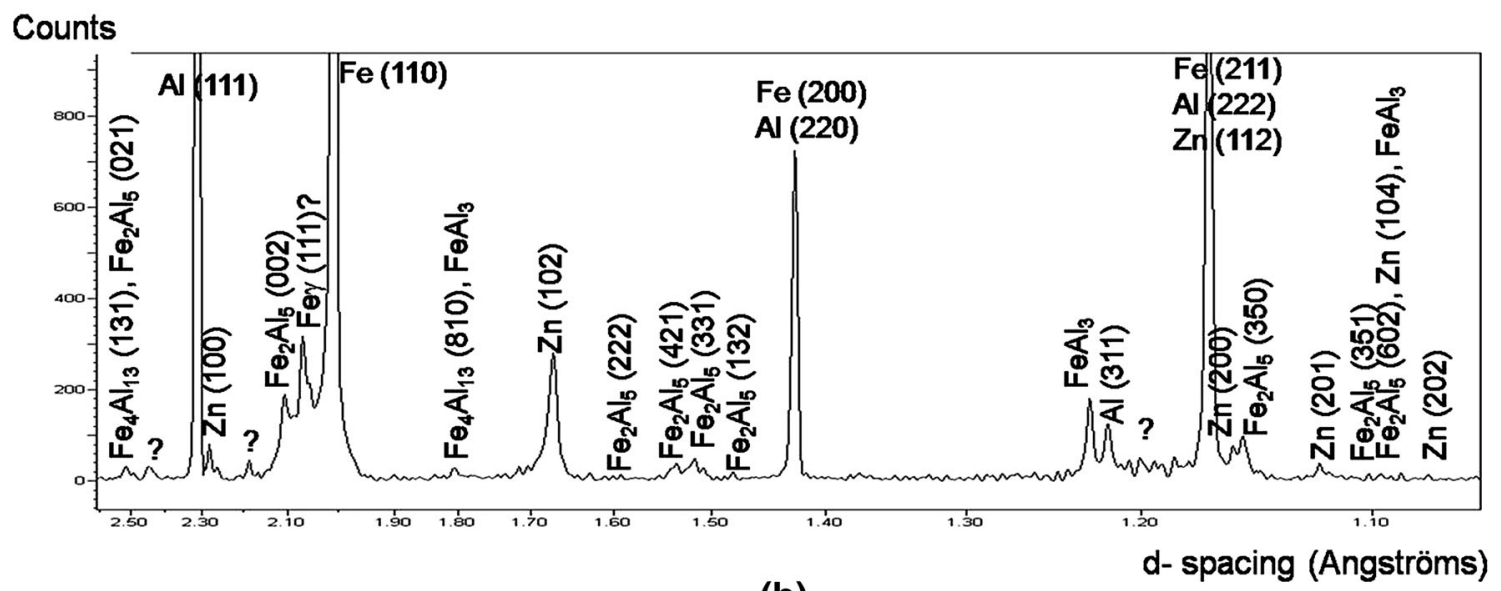

(b)

Fig. 9-X-ray diffraction patterns of (a) the Al 1050-DP450 steel joint and (b) the Al 1050-galvanized DP450 steel joint.

pure $\mathrm{Zn}$ layer thickness can thus be divided by a factor of 5 at places where the $(\mathrm{Al}+\mathrm{Zn})$ layer is thick.

At the constricted parts of the interfacial zone (exemplified by the location of thin foil 3 in Figure 12), an additional $(\mathrm{Al})_{\mathrm{Zn}}, \mathrm{Al}-10$ at. pct $\mathrm{Zn}$, solid solution is observed adjacent to Al (Figure 14). The width of this layer is approximately $200 \mathrm{~nm}$ (Figure 14).

\section{Mechanical properties of the joint}

The hardness profiles across the interface and along the Y normal direction of both joints are depicted in Figure 15.

On the Al side, no softening originating from an extended heat-affected zone (HAZ) is observed, which is consistent with the absence of this zone. The latter deduction is confirmed by the invariability of the grain size and shape compared to those in the base material. The absence of an HAZ also agrees with both the high thermal conductivity of $\mathrm{Al}$ and the very short welding time. In the case of the joint with the coated steel, softening is observed close to the interface, which is very likely due to the presence of the $\mathrm{Zn}$ and $(\mathrm{Zn}+\mathrm{Al})$ layers (Figure 15).

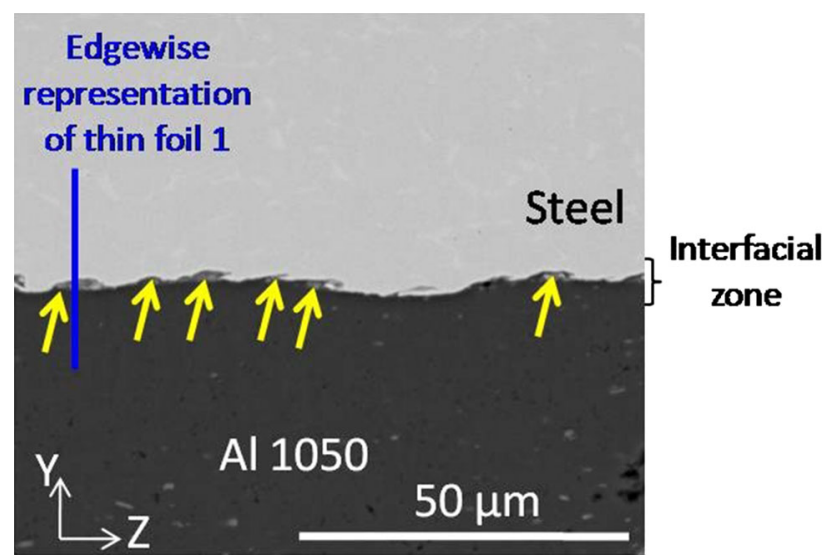

Fig. 10-Pockets (indicated by yellow arrows) containing thick IMCs along the interface of the Al 1050-uncoated steel joint observed in the $\mathrm{X}-\mathrm{Y}$ transverse section (BSE/SEM) (Color figure online).

It is worth noting that the microhardness profiles presented here are similar to other results, ${ }^{[118]}$ but they differ from those of Yu et al., who noted hardening over a distance of $50 \mu \mathrm{m}$ from the AA3003-low-carbon steel 

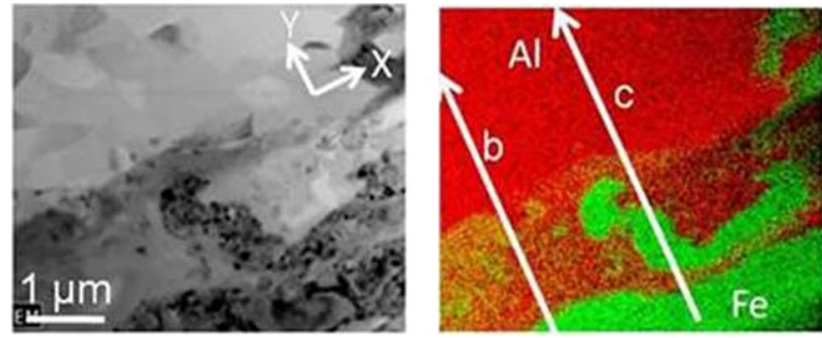

(a)
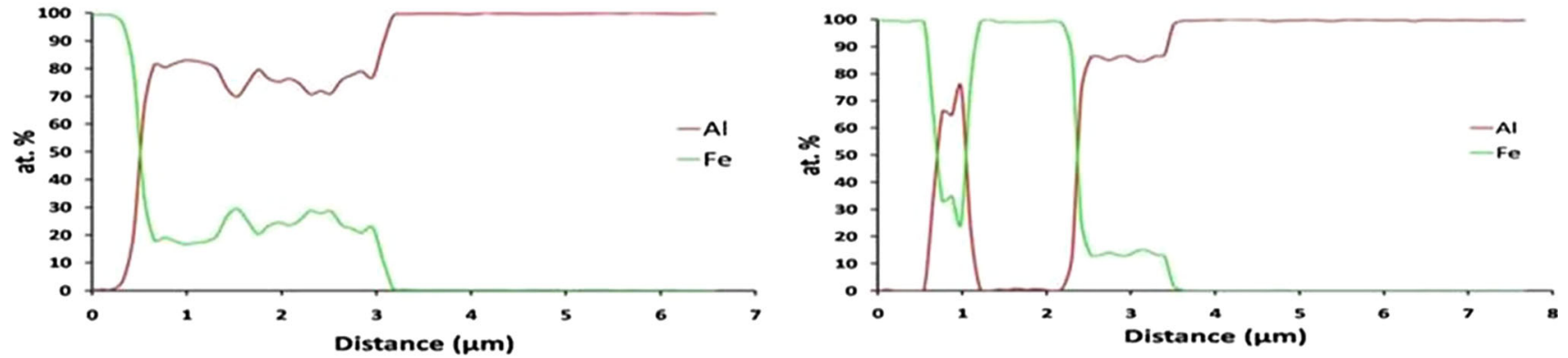

(b)

Fig. 11-Thin foil 1 (see its location in Fig. 10). (a) Interfacial zone of the Al 1050-uncoated steel joint in the X-Y transverse section (bright field-STEM) and combined Al-Fe X-ray map (EDX) [Al is colored in red and $\mathrm{Fe}$ in green]; $(b)$ and $(c)$ : $\mathrm{Al}$ and Fe quantitative profiles along the lines (b) and (c) drawn in panel (a) (Color figure online).
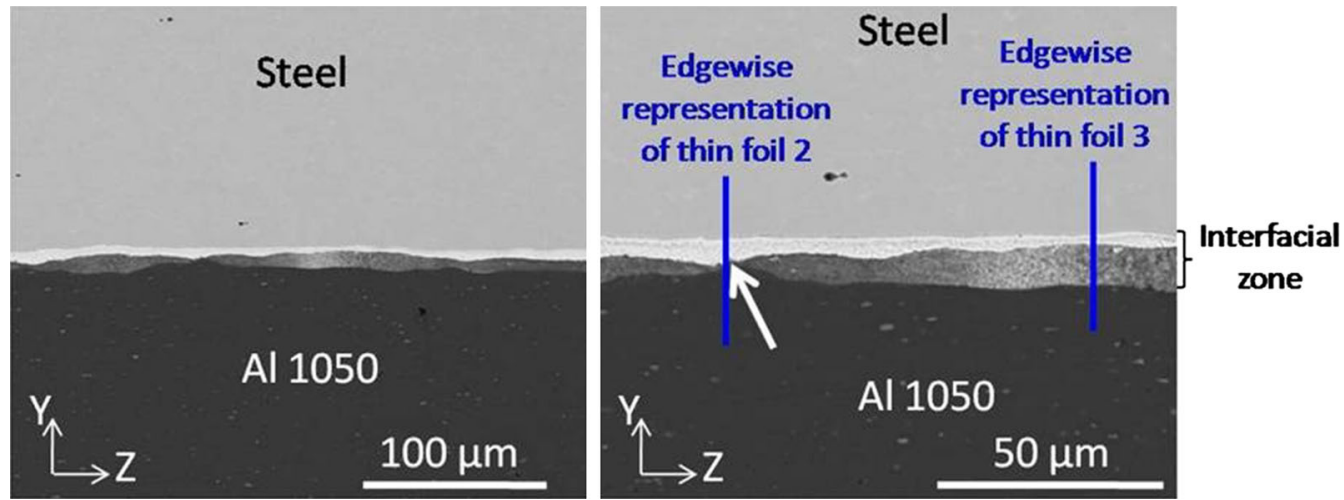

Fig. 12-Interfacial zone of the Al 1050-galvanized steel joint in the $\mathrm{X}-\mathrm{Y}$ transverse section (BSE/SEM). In the interfacial zone, Zn is the brightest phase.

joint interface because at once of the presence of IMCs at the interface, of grain size refinement and of strain hardening on both sides of the interface. ${ }^{[109]}$ In the current case of the joint formed with the uncoated steel, the lack of detection of hardening close to the interface is very likely due to the use of an important load for indentation and to an overly large measurement interspacing. Strengthening due to the presence of both hard $\mathrm{FeAl}_{3}$ IMCs and fine recrystallized grains is expected on the Al side of the interface. According to the Hall-Petch relationship, the grain size effect must be significant in aluminum as it should lead to about an approximately $30 \mathrm{MPa}$ hardening compared to the one close to $85 \mathrm{MPa}$ yield strength of the base material. In contrast to the previous interpretation of $\mathrm{Yu}$ et al., ${ }^{[109]}$ strain hardening is not efficient in the present case, as suggested by the low density of dislocations on the $\mathrm{Al}$ side close to the interface (Figure 7(c)).
Table II and Figure 16 present the shear lap tensile properties of both kinds of joints. According to the continuity of the load-displacement curves, there is no shift between the joining partners before reaching the peak strength. The ultimate tensile force is higher for the joint with the uncoated steel. The maximum displacement is rather low, independently of the joint type. However, the shear lap behavior of the joint with the uncoated steel is very similar to that of Al 1050-Al 1050 joints prepared with the same conditions (Table II).

Sound, i.e., not macroscopically damaged, joints were obtained when fracture occurred by ductile tearing in the $\mathrm{Al}$ base material and in front of the transverse part of the joint. The latter joints are characterized by a progressive decrease of the load with displacement.

In contrast, for half of the joints with the galvanized steel, named joint 1 , the load dropped rapidly after its peak, as fracture occurred in the transverse part of the 

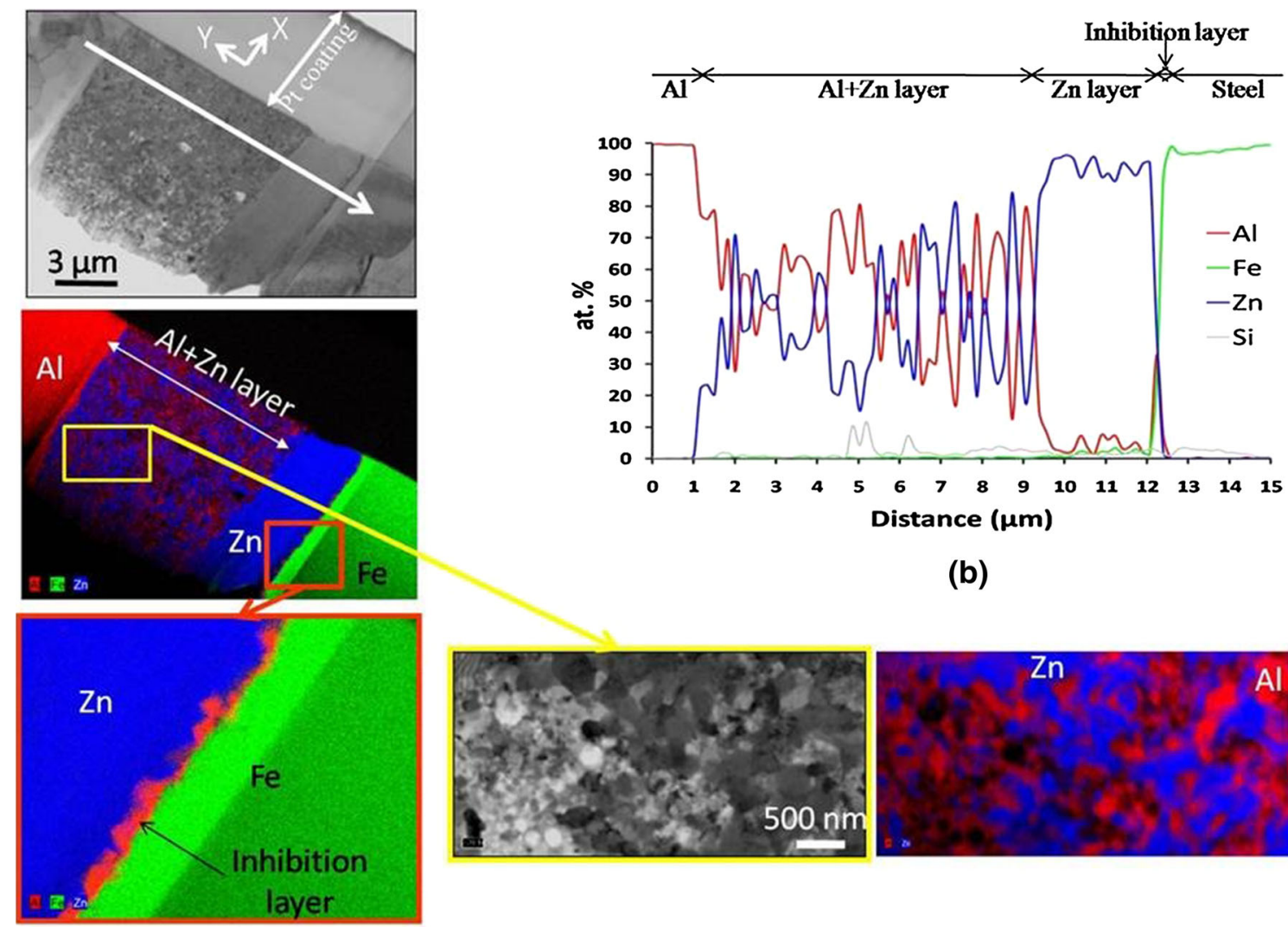

(b)
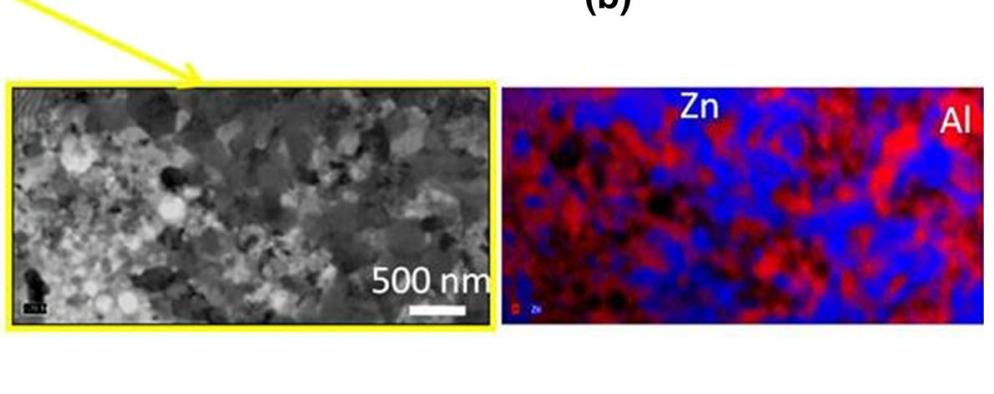

(a)

Fig. 13-Thin foil 2 (see its location in Fig. 12). (a) X-Y transverse section of the Al 1050-galvanized steel joint (bright field-STEM) and combined $\mathrm{Al}-\mathrm{Zn}-\mathrm{Fe} \mathrm{X}$-ray map (EDX) [Al is colored in red, $\mathrm{Fe}$ in green, and $\mathrm{Zn}$ in blue]; (b) $\mathrm{Al}, \mathrm{Fe}, \mathrm{Si}$, and $\mathrm{Zn}$ quantitative profiles along the heavy white arrow drawn in panel a. The brightest green band is due to a zone that was less thinned during the preparation of the thin foil by FIB (Color figure online)
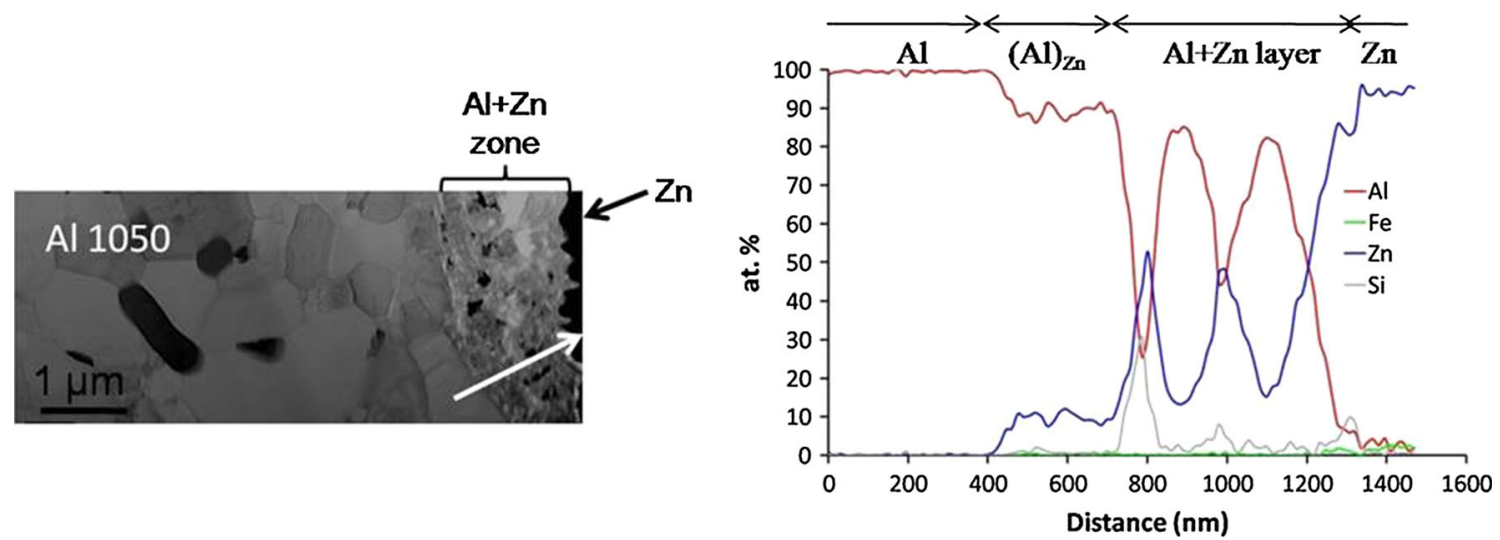

Fig. 14-Thin foil 3 (see its location in Fig. 12). Al side of the X-Y transverse section of the interfacial zone in the Al 1050-galvanized steel joint (bright field-STEM) and $\mathrm{Al}, \mathrm{Fe}, \mathrm{Si}$, and $\mathrm{Zn}$ quantitative profiles along the white arrow drawn in the micrograph.

weld around the $\mathrm{C}$ zone denoted in Figure 17. Figures 17(a) and (b) display the general character of both sides of the fracture surface. The fracture area on the galvanized steel side is essentially enriched in $\mathrm{Zn}$, whereas some parts are Al-rich (Figures 17A, B, and C). The latter islands are obviously plastered in the shear direction over the $\mathrm{Zn}$ layer (Figure 17(D)), which indicates that they were the last zones to break during testing. 


\section{DISCUSSION}

\section{A. Interface Waviness}

During MPW, a sudden temperature increase is observed at the Al-steel interface because of the loss of kinetic energy due to impact. Heating is very likely significant because the peak temperature is expected to reach $1473 \mathrm{~K}\left(1200{ }^{\circ} \mathrm{C}\right)$ in MPW of AA6061-T6 according to thermomechanical simulations. ${ }^{[135]}$ This temperature increase, combined with the high rate of deformation, leads to material softening (and even sometimes melting), which promotes the formation of a wavy joint interface. ${ }^{[103,106,116]}$

In the present case, the observation of wavy interfaces is consistent with the studies by Watanabe ${ }^{[136]}$ and Aizawa $^{[105]}$ but differs from some previous results that report a planar interface at MPW Al-steel joints. ${ }^{[103]}$ The differences in interfacial features (wave amplitude and periodicity) directly depend on numerous parameters, namely, (1) the evolution of the collision angle in the oblique configuration ${ }^{[107]}$ and the magnitude of the discharge energy, both of which govern the collision velocity, (2) the flyer plate thickness, ${ }^{[103]}$ and (3) instabilities in the magnetic signal during the process.

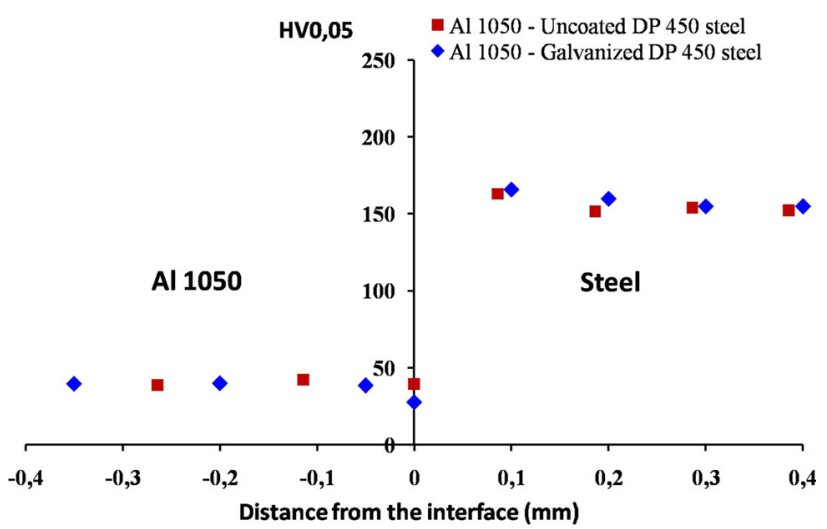

Fig. 15-Hardness profiles along the plate thickness (Y direction) for the Al 1050-DP 450 steel and Al 1050-galvanized DP 450 steel joints.
A comparison of Figures 10 and 12 shows that the waviness of the interface is more pronounced for the uncoated steel. This observation is very interesting because both kinds of welds were obtained with the same process settings. This suggests that waviness is promoted by the ease of plastic deformation of the two base materials. Indeed, Zn presents fewer slip systems than steel or aluminum.

In addition, in the case of the Al-uncoated steel joint, the waviness is further amplified by the insertion of hard Fe fragments, expelled by the spallation of the steel surface into softer Al during impact. The latter phenomenon has previously been observed in a study by Watanabe. ${ }^{[136]}$

\section{B. Microstructure of the Interfacial Zone}

\section{Defect-free joints}

It is worth noting that with the present process parameters, the microstructure of the magnetic pulsed joints is defect-free.

\section{Joints without $\mathrm{Zn}$}

In the absence of $\mathrm{Zn}$ and in accordance with data from the literature, ${ }^{[105,120]}$ intermetallic compounds are formed at the Al-steel interface. Some $\mathrm{FeAl}_{3}$

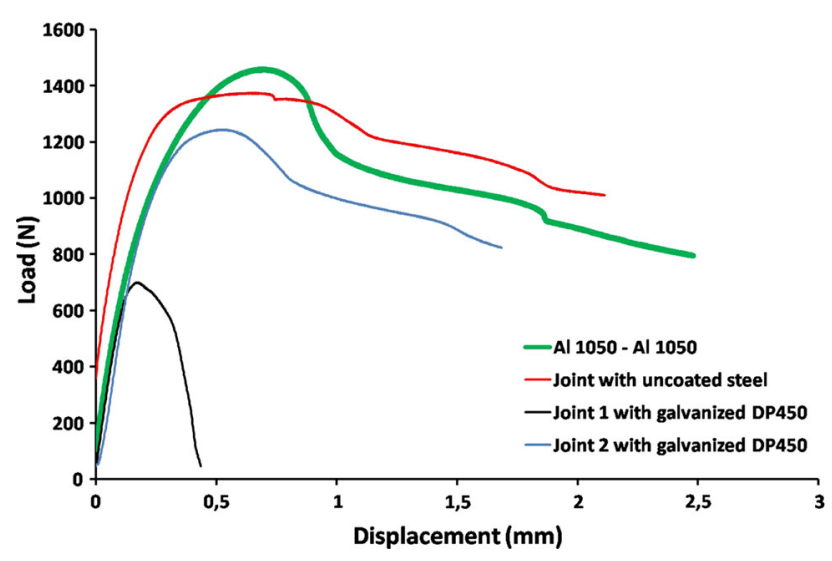

Fig. 16-Typical shear lap tensile curves of the joints.

Table II. Shear Lap Tensile Properties

\begin{tabular}{|c|c|c|c|c|c|}
\hline Material & $\begin{array}{l}\text { Total Displacement } \\
(\mathrm{mm})\end{array}$ & $\begin{array}{c}\text { Maximum Tensile Force } \\
(\mathrm{N})\end{array}$ & $\begin{array}{l}\text { Joint } \\
\text { Efficiency } \\
\text { (Pct)** } \\
\text { [Force] }\end{array}$ & $\begin{array}{c}\text { Joint Efficiency } \\
\text { (Pct)** } \\
{[\text { Displacement] }}\end{array}$ & $\begin{array}{l}\text { Fracture } \\
\text { Location }\end{array}$ \\
\hline Al 1050-Al 1050 & $1.93 \pm 0.57$ & $1457 \pm 59(3$ tests $)$ & - & - & $\mathrm{Al}$ \\
\hline $\begin{array}{l}\text { Joint with uncoated } \\
\text { steel }\end{array}$ & $1.67 \pm 0.17$ & $1359 \pm 129$ (3 tests) & 93 & 86.5 & $\mathrm{Al}$ \\
\hline $\begin{array}{l}\text { Joint with galvanized } \\
\text { steel }\end{array}$ & $\begin{array}{l}0.85 \pm 0.45 \\
{[\text { Joint } 1]^{*}} \\
1.50 \pm 0.25 \\
{[\text { Joint } 2]^{*}}\end{array}$ & $\begin{array}{l}835 \pm 135 \text { (2 tests }) \\
{[\text { Joint } 1]^{*}} \\
1208 \pm 36(2 \text { tests }) \\
{[\text { Joint } 2]^{*}}\end{array}$ & $\begin{array}{l}57 \\
83\end{array}$ & $\begin{array}{l}44 \\
77.7\end{array}$ & $\begin{array}{l}\text { weld } \\
\text { Al }\end{array}$ \\
\hline
\end{tabular}

*Joints 1 and 2 refer to both kinds of tensile behavior exemplified in Fig. 16

**Due to the nature of the shear lap tensile test, the coefficients of efficiency must be calculated via comparison with the properties of a joint, in the present case, the Al 1050-Al 1050 joint. 

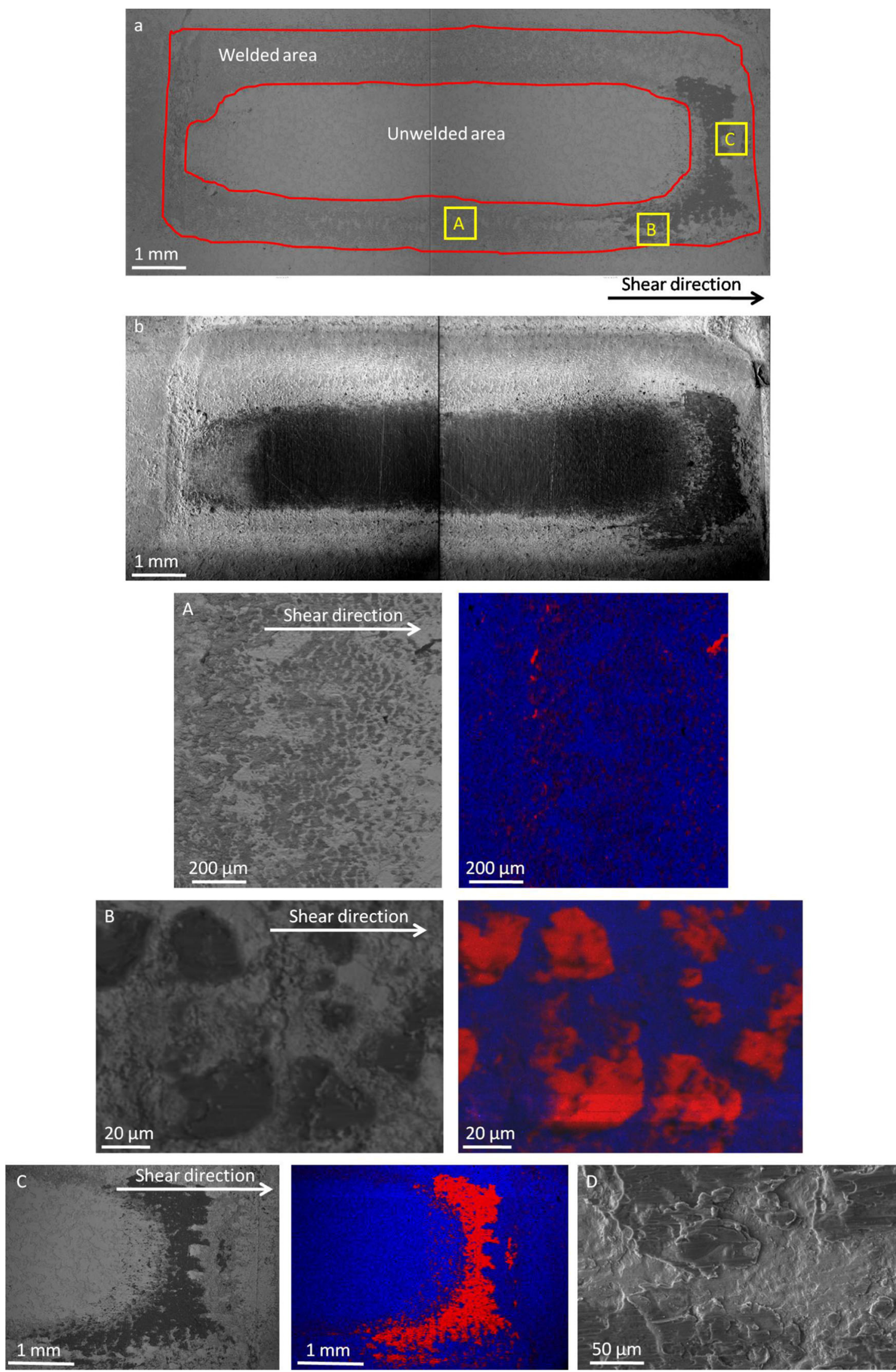

Fig. 17-Fracture surface of joint 1: (a) galvanized steel side and (b) $\mathrm{Al}$ side, with $\mathrm{A}, \mathrm{B}$, and $\mathrm{C}$ being magnified views with corresponding combined $\mathrm{Al}-\mathrm{K} \alpha$ (red) and $\mathrm{Zn}-\mathrm{K} \alpha$ (blue) X-ray maps of the zones encircled in micrograph (a), and (D) a close-up of zone C. 
compounds up to $2.5 \mu \mathrm{m}$ thick are predominantly found on the Al side of the interface as shown by XRD and TEM analyses (Figures 9(a) and 10). These IMCs are more specifically located in pockets distributed along the wavy interface and in close contact with the steel fragments that are torn and spread into the softer $\mathrm{Al}$ during impact. Such observations are consistent with previous works. ${ }^{[120,136]}$ A close examination of the literature data, not presented here to be concise, suggests that the discontinuity of the joint microstructure seems to result from a reduced input voltage and a low discharge energy. The IMC nature is consistent with a previous work, ${ }^{109]}$ whereas other studies report the presence of discrete particles of both $\mathrm{FeAl}_{3}$ and $\mathrm{Fe}_{2} \mathrm{Al}_{5},{ }^{[107]} \mathrm{Fe}_{4} \mathrm{Al}_{13}$ or $\mathrm{Fe}_{2} \mathrm{Al}_{5},{ }^{[120]}$ or continuous layers of $\mathrm{Fe}_{4} \mathrm{Al}_{13}$ and $\mathrm{FeAl}_{3}{ }^{\left[{ }^{[109]}\right.}$ It is worth noting that neither a glassy $(\mathrm{Al}+\mathrm{Fe})$ zone $^{[111]}$ nor an oversaturated $(\mathrm{Fe})_{\mathrm{Al}}$ solid solution was observed, which is in contrast to other studies. ${ }^{[107,111]}$ The observed discrepancies very likely result from differences in parameter settings. Process parameters are, however, often not reported in the literature, which makes the comparison difficult. In addition, the different natures of the steel used here compared to steel used by other authors may also explain the discrepancies in results because steels of different chemical compositions will have different material flow responses during MPW, exacerbating the variability of the microstructure.

In the current case, on the $\mathrm{Al}$ side of the interface, the predominant formation of $\mathrm{FeAl}_{3}$ among all the $\mathrm{Fe}_{\mathrm{x}} \mathrm{Al}_{\mathrm{y}}$ IMCs reported in the equilibrium phase diagram ${ }^{[4]}$ can be questioned.

The formation of $\mathrm{FeAl}_{3}$ and $\mathrm{Fe}_{4} \mathrm{Al}_{13}$ generates a volume increase of 5764 pct vs 715 pct, 283 pct, and 4 pct for $\mathrm{Fe}_{2} \mathrm{Al}_{5}, \mathrm{Fe}_{3} \mathrm{Al}$, and $\mathrm{FeAl}$, respectively, with respect to the Al matrix. Accordingly, the formation of $\mathrm{FeAl}_{3}$ should not have been promoted because during MPW, the Al flyer piece is more plastically deformed than steel and compressive residual stresses are already constrained close to the interface. The formation of $\mathrm{FeAl}_{3}$ is, however, aided by its compressibility, as it presents a lower bulk modulus than $\mathrm{Fe}_{2} \mathrm{Al}_{5}$, i.e., $284 \mathrm{GPa}$ vs $475 \mathrm{GPa}^{[137]}$ The latter argument is nevertheless doubtful because of the plastic nature of the lattice deformation.

In addition, according to the effective heat of formation model, the first intermetallic phase to nucleate would be $\mathrm{Fe}_{2} \mathrm{Al}_{5}$ which possesses the most negative heat of formation at the composition corresponding to the lowest temperature of the liquidus in the Al-Fe system. ${ }^{[138]}$ In contrast, the Walser-Bené model predicts that the first phase to nucleate would be $\mathrm{FeAl}_{3}$, which is the congruent phase immediately adjacent to the low-temperature eutectic phase in the Al-Fe phase diagram. ${ }^{[139]}$ Another factor favorable for the preferential formation of $\mathrm{FeAl}_{3}$ is the large extent of its composition range. Indeed the extent of composition is as efficient as diffusion for the growth of phases. $^{[140]}$

In addition, although the materials are not at equilibrium during MPW, the very low equilibrium solubility of $\mathrm{Fe}$ in $\mathrm{Al}(0.025 \text { at. pct })^{[4]}$ and the local chemical composition could also explain the preferential formation of $\mathrm{FeAl}_{3}$, which is the most Al-rich $\mathrm{Fe}_{\mathrm{x}} \mathrm{Al}_{\mathrm{y}}$ IMC on the Al side.

Finally, it is important to emphasize that some rather large IMC particles are formed in spite of the short $(\mu \mathrm{s})$ welding time. The high kinetics of formation (some meters per second) is very likely assisted by the very high deformation rate (Table III). Two explanations are proposed. In the first hypothesis, welding proceeds in the solid state. Due to high strain rates and great pressures up to $10^{5} \mathrm{MPa}$, Al would behave like a high velocity fluid, although it remains solid. ${ }^{[106,120,141]}$ The viscous state would be induced by a high heat input and/ or by a great atomic disorder due to a high density of defects generated by the high strain rate at the interface. The high density of dislocations and the high oversaturation of vacancies ${ }^{[142-145]}$ produced during impact should markedly increase the diffusion of elements. The dislocation density is, for instance, estimated at $10^{11}$ dislocations per $\mathrm{cm}^{2}$ after explosion welding. ${ }^{[144]}$ In the second assumption, the heating effect due to a high strain rate for a short time ${ }^{[135]}$ may induce local melting followed by rapid solidification at the interface. ${ }^{[106,110,111,113]}$ In this case, diffusion is exacerbated during the process, which leads to the fast formation of IMCs. However, because of the absence of clue of solidification structures, the solid-state mechanism is the most likely mechanism in the present case. This contradicts assertions in the literature in which pockets at interfaces (see Figures 8 and 10) should result from local melting. [110]

\section{Joints with the galvanized steel}

In the presence of the galvanized coating, except for the 150-nm-thick and continuous inhibition layer, no IMC is detected on either side of the joint interface. Instead, some pure zinc, with a thickness smaller than the primitive $\mathrm{Zn}$ coating, is observed together with a zone of interdiffusion.

A comparison with the 6 to $10 \mu \mathrm{m}$ initial thickness of the $\mathrm{Zn}$ coating shows that, in the joint, the pure $\mathrm{Zn}$ layer thickness can be divided by 5 when the $(\mathrm{Al}+\mathrm{Zn})$ layer is thick (approximately $9 \mu \mathrm{m}$ ) (Figure 13). Two assumptions can be made to explain this observation.

The first assumption would be that Al diffused into $\mathrm{Zn}$ over a distance greater than that over which $\mathrm{Zn}$ migrated within Al. This explanation is indeed consistent with the different orders of magnitude of both diffusion coefficients. The diffusion coefficient of $\mathrm{Zn}$ in $\mathrm{Al}$ is $2.17 \times 10^{-17}, 1.57 \times 10^{-15}$, and $3.63 \times 10^{-10} \mathrm{~cm}^{2}$ $\mathrm{s}$ at $383(110), 433(160)$, and $688 \mathrm{~K}\left(415^{\circ} \mathrm{C}\right)$, respectively, ${ }^{[4]}$ whereas the diffusion coefficient of $\mathrm{Al}$ in $\mathrm{Zn}$ is equal to $3.16 \times 10^{-9} \mathrm{~cm}^{2} / \mathrm{s}$ at $573 \mathrm{~K}\left(300{ }^{\circ} \mathrm{C}\right) .{ }^{[146]}$ The deformation very likely further promotes the diffusion of $\mathrm{Al}$ in $\mathrm{Zn}$ since the distance covered by the elements during the process (i.e., in approximately $15 \mu \mathrm{s}$ ) is equal to a few micrometers, which is greater than the distance of $0.24 \mu \mathrm{m}$ calculated by considering the previous diffusion coefficients measured in deformation-free samples. Only Al should diffuse in $\mathrm{Zn}$ since the original $\mathrm{Zn}$ coating thickness is very close to the total thickness of both the $(\mathrm{Al}+\mathrm{Zn})$ and $\mathrm{Zn}$ layers after welding. 


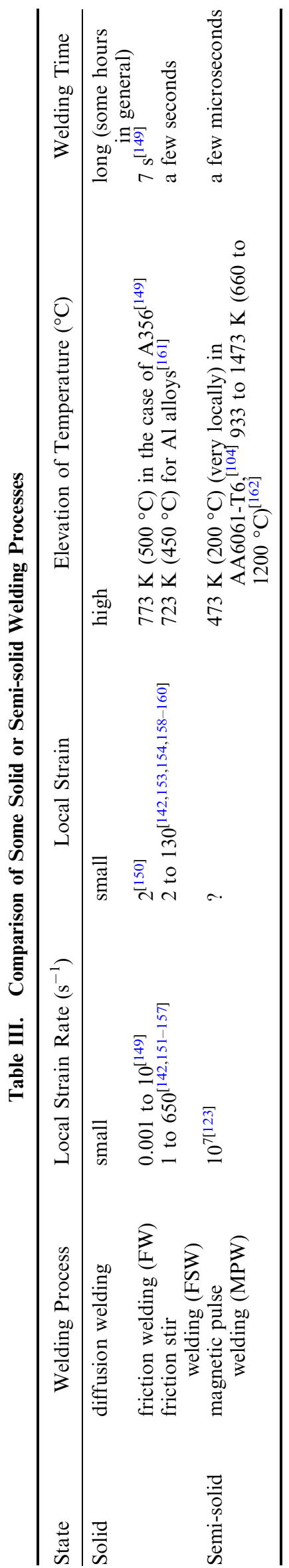

A second explanation would be fracturing of the brittle zinc layer under the impact effect followed by filling of the empty spaces (let by the cracks) by viscous Al.

Moreover, as previously stated for the case of the Al-uncoated steel joint, the absence of clue of solidification structures suggests that joining very likely occurred in the solid state in spite of the easy melting of $\mathrm{Zn}$ with its low melting temperature, i.e., $419.5^{\circ} \mathrm{C}$.

\section{Role and interest of zinc}

Without the galvanized coating, only discrete and thin $\mathrm{Fe}_{x} \mathrm{Al}_{y}$ IMC particles are formed, whereas the presence of $\mathrm{Zn}$ contributes to the formation of both a bi-phased $(\mathrm{Al}+\mathrm{Zn})$ layer and an $(\mathrm{Al})_{10}$ at. pct $\mathrm{Zn}$ solid solution. The comparison of both kinds of joints proves that the presence of $\mathrm{Zn}$ hinders the formation of $\mathrm{Fe}_{x} \mathrm{Al}_{y}$ IMCs at the interface. Indeed, the presence of the $\mathrm{Fe}_{2} \mathrm{Al}_{5} \mathrm{Zn}_{x}$ inhibition layer on the steel hinders the diffusion of $\mathrm{Fe}$ and, subsequently, the formation of both $\mathrm{Fe}_{x} \mathrm{Zn}_{y}$ and $\mathrm{Fe}_{x} \mathrm{Al}_{y}$ IMCs.

From the mechanical point of view, the comparison between the results of the shear lap tensile tests suggests that the presence of a continuous $\mathrm{Zn}$ layer is more deleterious than that of discrete IMCs particles at the interface. Discrete IMC particles may not be redhibitory with regard to joint fracture. ${ }^{[19,56,147]}$ Otherwise, it is worth noting the absence of the $(\mathrm{Al}+\mathrm{Zn})$ bi-phased layer over the fracture surface (Figure 17). This observation may result from both the insufficient spatial resolution of the present SEM images and/or the high plasticity of the bi-phased layer. The latter hypothesis agrees with both the submicrometer size and the chemical composition of the grains. Superplasticity was observed in Zn-22 at. pet Al alloy at room temperature and at a similar strain rate. ${ }^{[148]}$

\section{Comparison of $M P W$ with other welding processes} to join Al and steel

A comparison of the current results with those summarized in Table IV proves that the nature and thickness of the IMCs formed at the $\mathrm{Al} /$ steel interface depend on the nature of the parent and filler materials, on the process parameter settings and, therefore, on the liquid or solid nature of the welding process. The significant sizes of most of the IMCs compiled in Table IV suggest that they were formed under sub-optimal processing conditions.

In fusion welding processes, chemical diffusion occurs easily because of the liquid state, and the process duration is sufficient to allow the formation of various types of IMCs with thicknesses up to $35 \mu \mathrm{m}$ (Table IV). The preferential formation of $\mathrm{Fe}_{2} \mathrm{Al}_{5}$ (and less frequently of $\mathrm{FeAl}_{3}$ ) is generally noted when only $\mathrm{Al}$ melts. ${ }^{[3,16]}$ When both steel and aluminum are in the liquid state, such as in the case of anisothermal laser welding, ${ }^{[39]}$ additional Fe-rich intermetallic compounds, namely, $\mathrm{FeAl}$ and $\mathrm{FeAl}_{2}$, form.

In the same way, diffusion bonding at the solid state and at a high homologous temperature for the material with a lower melting point favors the generation of different kinds of IMCs all the more when the holding time is long, i.e., one to several hours (Table IV). 
Regarding the semi-solid and solid processes, the formation of IMCs will depend on the thermomechanical parameters differing by several orders of magnitude. For MPW, the strain rate is $10^{5}\left(10^{6}\right)$ times that for FSW (FW), the temperature is lower than in FW and FSW, and the welding time is far shorter (Table III). According to Table IV, the tendency for slightly easier formation of $\mathrm{Fe}_{2} \mathrm{Al}_{5}$ during $\mathrm{FSW}$ and $\mathrm{FeAl}_{3}$ during MPW may suggest that the kinetics of formation of $\mathrm{FeAl}_{3}$ is very rapid with a high vacancy density. This remark agrees with the easier accommodation of the very important lattice distortion due to the formation of the asymmetric monoclinic $\mathrm{FeAl}_{3}$ lattice in a disordered state rather than in a perfect crystal lattice.

\section{CONCLUSIONS}

The current study of planar joints using magnetic pulse welding led to the following conclusions:
- Some defect-free Al-galvanized, or not, steel joints characterized by a wavy interface were developed by using magnetic pulse welding.

- In the uncoated steel case, both $\mathrm{FeAl}_{3}$ particles and Fe fragments were formed on the Al side of the joint.

- With regard to the joint with galvanized steel, two interfacial layers occurred, namely, an $(\mathrm{Al})_{\mathrm{Zn}}$ solid solution and an $(\mathrm{Al}+\mathrm{Zn})$ bi-phased layer. The $\mathrm{Zn}$ layer enables to avoid the formation of $\mathrm{Fe}_{x} \mathrm{Al}_{y}$ intermetallic particles at the Al-steel interface.

- Despite the presence of intermetallic compounds, the joints with uncoated steel present better mechanical properties than those with galvanized steel.

Table IV. Nature and Thickness of the Phases Formed at Al/Steel Interfaces for Joints Developed with Various Processes

\begin{tabular}{|c|c|c|c|c|c|}
\hline State & $\begin{array}{l}\text { Joining } \\
\text { Process }\end{array}$ & $\begin{array}{c}\text { Galvanized }(\mathrm{G}) \text { or Uncoated } \\
\text { Steel }(\mathrm{UG}) / \text { filler }\end{array}$ & $\begin{array}{l}\text { Nature of Phases and Compounds at the } \\
\text { Interface }\end{array}$ & $\begin{array}{l}\text { Total IMC } \\
\text { Size }(\mu \mathrm{m})\end{array}$ & References \\
\hline \multirow[t]{27}{*}{ Liquid } & \multirow{4}{*}{$\begin{array}{l}\text { metal arc } \\
\text { joining } \\
\text { MIG }\end{array}$} & UG/A199.5 & $\mathrm{Fe}_{4} \mathrm{Al}_{13}, \mathrm{Fe}_{2} \mathrm{Al}_{5}$ & 3.5 & \multirow[t]{2}{*}{9} \\
\hline & & $\mathrm{UG} / \mathrm{AlSi} 5$ & $\mathrm{Fe}_{4} \mathrm{Al}_{13}, \mathrm{Fe}_{2} \mathrm{Al}_{5}, \mathrm{AlFeSi}$ & 2 & \\
\hline & & $\mathrm{UG} \& \mathrm{G} / \mathrm{A} 1 \mathrm{Si} 5$ & $\mathrm{Al}_{4.5} \mathrm{FeSi}$ (with metal) & 5 to 15 & 12 \\
\hline & & $\mathrm{UG} / \mathrm{Al}-12 \mathrm{Si}$ & $\alpha$-Al phase, $\mathrm{Al}$-Si eutectic phases, $\mathrm{Al}_{7.4} \mathrm{Fe}_{2} \mathrm{Si}$ & 2 to 12 & 7 \\
\hline & $\begin{array}{l}\text { cold metal } \\
\text { transfer }\end{array}$ & G & $\mathrm{Fe}_{2} \mathrm{Al}_{5}, \mathrm{FeAl}_{3}$ & 2.3 & 16 \\
\hline & TIG & $\begin{array}{l}\mathrm{UG} / \text { pure } \mathrm{Al} \\
\mathrm{UG} / \mathrm{AlSi} 5 \text { or AlSi12 }\end{array}$ & $\begin{array}{l}\mathrm{Fe}_{2} \mathrm{Al}_{5}, \mathrm{FeAl}_{3} \\
\left.(\mathrm{Fe}, \mathrm{Al}) \mathrm{Si}_{3}, \mathrm{Al}_{7.2} \mathrm{FeSi}\right)\end{array}$ & 5 to 35 & 10 \\
\hline & \multirow[t]{9}{*}{ laser welding } & $\mathrm{UG}$ & $\mathrm{Fe}_{2} \mathrm{Al}_{5}, \mathrm{FeAl}_{3}$ & \multirow[t]{2}{*}{25} & 32,33 \\
\hline & & $\mathrm{UG}$ & $\mathrm{Fe}_{4} \mathrm{Al}_{13}, \mathrm{Fe}_{2} \mathrm{Al}_{5}, \mathrm{FeAl}_{2}, \mathrm{FeAl}, \mathrm{Fe}_{3} \mathrm{Al}, \mathrm{FeAl}_{6}$ & & 34 \\
\hline & & UG? & $\mathrm{Fe}_{2} \mathrm{Al}_{5}, \mathrm{FeAl}_{3}$ & 10 & 40 \\
\hline & & $\mathrm{UG}$ & $\mathrm{Fe}_{2} \mathrm{Al}_{5}, \mathrm{FeAl}_{3}$ and $\mathrm{FeAl}_{2}$ & \multirow[t]{2}{*}{ - } & 37 \\
\hline & & - & $\begin{array}{l}\alpha \mathrm{Fe}(\mathrm{Al}), \mathrm{Fe}_{2} \mathrm{Al}_{5}, \mathrm{FeAl} l_{2}, \mathrm{FeAl}, \mathrm{FeAl}_{3} \text { [melt- } \\
\text { ing of } \mathrm{Al} \text { and } \mathrm{Fe} \text { ] }\end{array}$ & & 39 \\
\hline & & UG & $\mathrm{Fe}_{2} \mathrm{Al}_{5}, \mathrm{FeAl}_{3}$ & 30 & 41 \\
\hline & & UG & $\begin{array}{l}\mathrm{FeAl}_{3} \text { (with } \mathrm{Fe}_{2} \mathrm{Al}_{5} \text { islands) and } \mathrm{FeAl} \text { (with } \\
\mathrm{FeAl}_{3} \text { islands) }\end{array}$ & 4 to 5 & 42 \\
\hline & & UG & $\mathrm{FeAl}_{3}$ and $/$ or $\mathrm{Fe}_{2} \mathrm{Al}_{5}$ & 3 to 8 & 44 \\
\hline & & $\mathrm{G}$ & $\mathrm{FeAl}_{3}$ & 10 & 43 \\
\hline & $\begin{array}{l}\text { laser roll } \\
\text { welding }\end{array}$ & $\mathrm{UG}$ & $\mathrm{Fe}_{2} \mathrm{Al}_{5}, \mathrm{FeAl}_{3}, \mathrm{FeAl}$ & $4-5$ & 42 \\
\hline & \multirow[t]{5}{*}{ laser brazing } & $\mathrm{UG} \& \mathrm{G}$ & $\mathrm{FeAl}_{3}, \mathrm{Fe}_{2} \mathrm{Al}_{5}$ & & 38 \\
\hline & & $\mathrm{G}$ & $\mathrm{Fe}_{2} \mathrm{Al}_{5} \mathrm{Zn}_{x}$ & 10 & 48 \\
\hline & & $\mathrm{UG} / \mathrm{Al} / \mathrm{Zn}$ & $\begin{array}{l}\mathrm{Fe}_{2} \mathrm{Al}_{5} \mathrm{Zn}_{x}+\text { discrete } \mathrm{FeZn}_{10}+\text { Al-rich } \\
\text { amorphous phase }\end{array}$ & - & 62 \\
\hline & & G/AlSi5 & $\mathrm{Al}_{8} \mathrm{Fe}_{2} \mathrm{Si}, \mathrm{Fe}_{4} \mathrm{Al}_{13}, \mathrm{Al}_{2} \mathrm{Fe}$ & 1.5 to 13 & 49 \\
\hline & & $\mathrm{G} / \mathrm{Zn}-2 \mathrm{Al}$ & $\mathrm{Fe}_{2} \mathrm{Al}_{5}+$ significant amounts of $\mathrm{Si}$ and $\mathrm{Zn}$ & \multirow[t]{3}{*}{$<10$} & 35 \\
\hline & \multirow[t]{2}{*}{$\begin{array}{l}\text { electron beam } \\
\text { welding }\end{array}$} & $\mathrm{UG} / \mathrm{Ag}$ & $\begin{array}{l}{\left[\mathrm{Al}+\mathrm{Ag}_{2} \mathrm{Al}\right] \text { eutectic }\left(+\mathrm{FeAl}, \mathrm{FeAl}_{3} \text { with a }\right.} \\
\text { large beam offset })\end{array}$ & & 27 \\
\hline & & $\mathrm{UG} / \mathrm{Ag}-2 \mathrm{Mg}$ & $\begin{array}{l}\alpha \mathrm{Fe}(\mathrm{Al}), \mathrm{Al}(\mathrm{Ag}), \operatorname{Ag}(\mathrm{Al}), \delta-\left(\mathrm{Ag}_{2} \mathrm{Al}\right)+\text { little } \\
\quad \mathrm{FeAl}[\mathrm{Al} \text { and } \mathrm{Fe} \text { melting] }\end{array}$ & & 28 \\
\hline & \multirow{4}{*}{$\begin{array}{l}\text { resistance spot } \\
\text { welding } \\
\text { brazing in } \\
\text { furnace }\end{array}$} & UG & $\mathrm{FeAl}_{3}, \mathrm{Fe}_{2} \mathrm{Al}_{5}$ & \multirow{3}{*}{$\begin{array}{l}1.5 \\
2 \text { to } 5\end{array}$} & 17,18 \\
\hline & & UG & $\mathrm{Fe}_{2} \mathrm{Al}_{5}$ & & 23 \\
\hline & & $\mathrm{UG} / \mathrm{Al}-12 \mathrm{Si}$ & $\mathrm{FeSiAl}_{5}, \mathrm{FeAl}_{3}$ & & 50 \\
\hline & & $\mathrm{UG} / \mathrm{A} 19.1 \mathrm{Si}-3.4 \mathrm{Cu}$ & $\delta(\mathrm{Al}, \mathrm{Fe}, \mathrm{Si}), \alpha-\mathrm{Al}(\mathrm{Si})$ & - & 51 \\
\hline
\end{tabular}


Table IV. Continued

\begin{tabular}{|c|c|c|c|c|c|}
\hline State & $\begin{array}{l}\text { Joining } \\
\text { Process }\end{array}$ & $\begin{array}{l}\text { Galvanized }(\mathrm{G}) \text { or } \\
\text { Uncoated Steel } \\
(\mathrm{UG}) / \text { filler }\end{array}$ & $\begin{array}{c}\text { Nature of Phases and Compounds at the } \\
\text { Interface }\end{array}$ & $\begin{array}{l}\text { Total IMC Size } \\
\qquad(\mu \mathrm{m})\end{array}$ & References \\
\hline \multirow[t]{9}{*}{ Semi-solid } & \multirow{3}{*}{$\begin{array}{l}\text { explosive } \\
\text { welding }\end{array}$} & UG? & $\mathrm{FeAl}, \mathrm{Fe}_{2} \mathrm{Al}_{5}$ & & 31 \\
\hline & & $\mathrm{UG}$ & $\mathrm{FeAl}, \mathrm{Fe} \mathrm{Al}_{2}, \mathrm{Fe} \mathrm{Al}_{3}, \mathrm{Fe} \mathrm{Al}_{6}$ & & 30 \\
\hline & & $\mathrm{UG} / \mathrm{Al} 1050$ & $\mathrm{FeAl}_{3}$ & - & 29 \\
\hline & \multirow{6}{*}{$\begin{array}{l}\text { magnetic } \\
\text { pulse } \\
\text { welding }\end{array}$} & $\mathrm{UG}$ & $\mathrm{Fe}_{4} \mathrm{Al}_{13}$ and $\mathrm{FeAl}_{3}$ & $?$ & 109 \\
\hline & & UG & $\begin{array}{l}\text { amorphous phase of } \mathrm{Al} \text { enriched with } \mathrm{Fe} \\
\text { atoms }\end{array}$ & $\begin{array}{l}\text { continuous } 26 \text { to } \\
100 \mathrm{~nm}\end{array}$ & 110 \\
\hline & & UG & $\mathrm{Fe}_{4} \mathrm{Al}_{13}$ or $\mathrm{Fe}_{2} \mathrm{Al}_{5}+$ some fragments of $\mathrm{Fe}$ & & 120 \\
\hline & & $\mathrm{UG}$ & $\begin{array}{l}\text { amorphous phase }(70 \text { at. pct } \mathrm{Fe}+28 \text { at. pct } \\
\mathrm{Al}) \text { oversaturated }(\mathrm{Fe})_{\mathrm{Al}} \text { solid solution }\end{array}$ & 0.01 & 111 \\
\hline & & UG & $\mathrm{FeAl}_{3}, \mathrm{Fe}_{2} \mathrm{Al}_{5}(\mathrm{Fe})_{\mathrm{Al}}$ solid solution & $\begin{array}{l}2 \text { to } 5 \text { discrete } \\
\text { particles }\end{array}$ & 107,108 \\
\hline & & $\mathrm{UG}$ & $\mathrm{FeAl}_{3}$ & $\begin{array}{l}\text { Up to } 90 \\
\text { discontinuous }\end{array}$ & 112,113 \\
\hline \multirow[t]{25}{*}{ Solid } & \multirow{3}{*}{$\begin{array}{l}\text { diffusion } \\
\text { welding }\end{array}$} & UG & $\mathrm{FeAl}_{3}, \mathrm{Fe}_{2} \mathrm{Al}_{5}\left(1 \mathrm{~h}\right.$ at $\left.600{ }^{\circ} \mathrm{C}\right)$ & 4 & 75 \\
\hline & & UG & $\mathrm{FeSiAl}_{5}, \mathrm{FeAl}_{3}, \mathrm{Fe}_{3} \mathrm{Al}$ & & $94,97,98$ \\
\hline & & $\mathrm{UG} / \mathrm{Ag}$ & $\mathrm{Ag}_{2} \mathrm{Al}, \mathrm{Ag}_{3} \mathrm{Al}$ & 0.5 & 64 \\
\hline & \multirow{3}{*}{$\begin{array}{l}\text { friction } \\
\quad \text { welding }\end{array}$} & $\mathrm{UG}$ & $\mathrm{FeAl}_{3}$ & & 65 \\
\hline & & $\mathrm{UG}$ & $\mathrm{FeAl}, \mathrm{Fe}_{3} \mathrm{Al}, \mathrm{Fe}_{2} \mathrm{Al}_{5}, \mathrm{FeAl}_{3}$ & & 66 \\
\hline & & UG & $\mathrm{Fe}_{2} \mathrm{Al}_{5}, \mathrm{FeAl}_{3}$ & 0.2 to 1 & 67,68 \\
\hline & \multirow{19}{*}{$\begin{array}{l}\text { friction stir } \\
\text { welding }\end{array}$} & $\mathrm{UG} / \mathrm{Zn}$ & $\mathrm{FeAl}_{3}(\mathrm{Zn})$ & 4.5 & 56 \\
\hline & & & $\begin{array}{l}\mathrm{Fe}_{2} \mathrm{Al}_{5}(\mathrm{Zn}) \\
+ \text { eutectic } \mathrm{Al}-\mathrm{Zn}+\mathrm{Zn}-40 \text { at pct } \mathrm{Al} \text { over- } \\
\quad \text { saturated solid solution at retreating side }\end{array}$ & 1.4 & \\
\hline & & $\mathrm{UG}$ & $\mathrm{Fe}_{2} \mathrm{Al}_{5}, \mathrm{FeAl}_{3}$ & $<2$ & $\begin{array}{l}71 \\
\text { through } \\
87\end{array}$ \\
\hline & & UG & $\mathrm{Fe}_{4} \mathrm{Al}_{13}, \mathrm{Fe}_{2} \mathrm{Al}_{5}$ & 5 & 70 \\
\hline & & $\mathrm{UG}$ & $\mathrm{FeAl}, \mathrm{FeAl}_{3}$ & 0.2 to 43 & 69 \\
\hline & & $\mathrm{UG}$ & $\mathrm{Fe}_{2} \mathrm{Al}_{5}, \mathrm{FeAl}_{3}$ & $<0.2$ & 73 \\
\hline & & $\mathrm{UG}$ & $\mathrm{FeAl}_{3}$ & $<1.3$ & 110 \\
\hline & & UG & $\mathrm{Fe}_{2} \mathrm{Al}_{5}$ & 0 to 23 & 75 \\
\hline & & UG & $\mathrm{Fe}_{4} \mathrm{Al}_{13}, \mathrm{Fe}_{2} \mathrm{Al}_{5}$ & $<2$ & 76 \\
\hline & & $\mathrm{UG}$ & $\mathrm{FeAl}_{3}$ & 2.5 to 25 & 77 \\
\hline & & UG & $\mathrm{FeAl}_{2}, \mathrm{Fe}_{2} \mathrm{Al}_{5}$ & 1 to 2.5 & 79 \\
\hline & & UG & $\mathrm{FeAl}_{2}, \mathrm{Fe}_{2} \mathrm{Al}_{5}, \mathrm{Fe}_{4} \mathrm{Al}_{13}$ & 0.7 to 1.8 & 80 \\
\hline & & $\mathrm{UG}$ & $\mathrm{Fe}_{2} \mathrm{Al}_{5}, \mathrm{FeAl}_{3}$ & 0.3 to 9.1 & 81 \\
\hline & & UG & $\mathrm{FeAl}, \mathrm{FeAl}_{3}$ & $<1$ & 82 \\
\hline & & $\mathrm{UG}$ & $\mathrm{Fe}_{2} \mathrm{Al}_{5}, \mathrm{FeAl}_{3}, \mathrm{FeAl}$ & 0.1 to 26 & 86 \\
\hline & & $\mathrm{G}$ & $\mathrm{Fe}_{2} \mathrm{Al}_{5}, \mathrm{Fe}_{4} \mathrm{Al}_{13}$ & 7.7 to 58.1 & 72 \\
\hline & & G & $\mathrm{Fe}_{2} \mathrm{Al}_{5}, \mathrm{FeAl}_{3}, \mathrm{FeAl}_{2}$ & $<5$ to 48 & 74 \\
\hline & & G & $\mathrm{FeAl}, \mathrm{Fe}_{2} \mathrm{Al}_{5}$ & 2 to 3 & 83 \\
\hline & & G & $\mathrm{Fe}_{4} \mathrm{Al}_{13}, \mathrm{Fe}_{3} \mathrm{Al}$ & 4.1 to 6.5 & 84,85 \\
\hline
\end{tabular}

Since $\mathrm{Fe}_{4} \mathrm{Al}_{13}$ and $\mathrm{FeAl}_{3}$ have very similar stoichiometry and crystallography, they are not differentiated.

When no specified, the continuous or discontinuous feature of the IMCs is unknown in spite of its mechanical importance.

\section{REFERENCES}

1. G. Liedl, R. Bielak, J. Ivanova, N. Enzinger, G. Figner, J. Bruckner, H. Pasic, M. Pudar, and S. Hampel: Phys. Proc., 2011, vol. $12 \mathrm{~A}$, pp. $150-56$

2. F. Möller and C. homy:Laser welding and brazing of dissimilar materials in Handbook of Laser Welding Technologies, S. Katayama, ed., Woodhead publishing, Cambridge, 2013, pp. $255-79$

3. G. Sierra: Etude métallurgique et mécanique de l'assemblage hétérogène accier/aluminium par les procédés laser et TIG, Université Montpellier 2, PhD, 2006.

4. E.A. Brandes and G.B. Brook: Smithells Metal Reference Book, 7th ed., Butterworth-Heinemann Ltd, Oxford, 1992.

5. L.H. Shah and M. Ishak: Mater. Manuf. Process., 2014, vol. 29 , pp. 928-33.
6. M.A. Miller and E.W. Mason: Weld. J., 1956, vol. 35 (7), pp. $323 \mathrm{~S}-8 \mathrm{~S}$

7. T. Murakami, K. Nakata, H. Tong, and M. Ushio: ISIJ Int., 2003, vol. 43 (10), pp. 1596-1602.

8. H.T. Zhang, J.C. Feng, P. He, and H. Hackl: Mater. Charact., 2007 , vol. 58 , pp. $588-92$

9. L.A. Jacome, S. Weber, A. Leitner, E. Arenholz, J. Bruckner, H. Hackl, and A.R. Pyzalla: Adv. Eng. Mater., 2009, vol. 11 (5), pp. $350-58$

10. J.L. Song, S.B. Liu, C.L. Yang, and C.L. Fan: J. Alloys Compd., 2009, vol. 488 (1), pp. 217-22.

11. H. Dong, L. Yang, C. Dong, and S. Kou: Mater. Sci. Eng. A, 2010 , vol. 527 , pp. $7151-54$.

12. H. Zhang and J. Liu: Mater. Sci. Eng. A, 2011, vol. 528, pp. 6179-85. 
13. H. Dong, L. Yang, C. Dong, and S. Kou: Mater. Sci. Eng. A, 2012, vol. 534, pp. 424-35.

14. Y. Su, X. Hua, and Y. Wu: Mater. Sci. Eng. A, 2013, vol. 578, pp. $340-45$.

15. R. Cao, G. Yu, J.H. Chen, and P.C. Wang: J. Mater. Process. Technol., 2013, vol. 213, pp. 1753-63.

16. L. Agudo, D. Eyidi, C.H. Schmaranzer, E. Arenholz, N. Jank, J. Bruckner, and A.R. Pyzalla: J. Mater. Sci., 2007, vol. 42, pp. $4205-14$.

17. R. Qiu, C. Iwamoto, and S. Satonaka: Mater. Charact., 2009, vol. 60 (2), pp. 156-59.

18. R. Qiu, C. Iwamoto, and S. Satonaka: J. Mater. Process. Technol., 2009, vol. 209, pp. 4186-93.

19. R. Qiu, S. Satonaka, and C. Iwamoto: Mater. Des., 2009, vol. 30, pp. $3686-89$

20. R. Qiu, H. Shi, K. Zhang, Y. Tu, C. Iwamoto, and S. Satonaka: Mater. Charact., 2010, vol. 61, pp. 684-88.

21. W. Zhang, D. Sun, L. Han, and Y. Li: Mater. Des., 2015, vol. 85, pp. 461-70.

22. X. Sun, E.V. Stephens, M.A. Khaleel, H. Shao, and M. Kimchi: Weld. J., 2004, vol. 83 (7), pp. 188-95.

23. M. Yasuyama, K. Ogawa, and T. Taka: Weld. Intern., 1996, vol. 10 (12), pp. 965-70.

24. H. Oikawa, T. Saito, T. Yoshimura, T. Nagase, and T. Kiriyama: Weld. Intern., 1996, vol. 10 (12), pp. 943-54.

25. H. Oikawa and T. Saito: Weld. Intern., 1999, vol. 13 (5), pp. 349-59.

26. K. Matsugi, Y. Wang, T. Hatayama, O. Yanagisawa, and K. Syakagohri: J. Mater. Process. Technol., 2003, vol. 135, pp. 75-82.

27. Z.B. Gang, C.G. Qing, Z.C. Guangl, and N.I.J. Qiang: Trans. Nonferrous Metals Soc. China, 2011, vol. 21, pp. 2592-96.

28. A. Grodzinski, J. Senkara, and M. Kozlowski: J. Mater. Sci., 1996, vol. 31, pp. 4967-73.

29. J.H. Han, J.P. Ahn, and M.C. Shin: J. Mater. Sci., 2003, vol. 38, pp. 13-18.

30. Y. Li, H. Hashimoto, E. Sukedai, Y. Zhang, and Z. Zhang: $J$. Elect. Microscopy, 2000, vol. 49 (1), pp. 5-16.

31. V.R. Ryabov, L.B. Pervukhin, G.A. Volferts, and V.V. Tsitsilin: Paton Weld. J., 1995, vol. 7 (12), pp. 690-93.

32. G. Sierra, P. Peyre, F. Deschaux-Beaumec, D. Stuart, and G. Fras: Mater. Sci. Eng. A, 2007, vol. 447, pp. 197-208.

33. N. Cavusoglu and H. Ozden: Weld. J., 2013, vol. 14, pp. 32-37.

34. K.J. Lee, S. Kumai, and T. Arai: Mater. Trans., 2005, vol. 46 (8), pp. $1847-56$.

35. H. Laukant, C. Wallmann, M. Müller, M. Korte, B. Stirn, H.G. Haldenwanger, and U. Glatzel: Sci. Technol. Weld. Join., 2005, vol. 10 (2), pp. 219-26.

36. R. Borrisutthekul, T. Yachi, Y. Miyashita, and Y. Mutoh: Mater. Sci. Eng. A, 2007, vol. 467, pp. 108-13.

37. J. Yang, Y.L. Li, and H. Zhang: Trans. Nonferrous Met. Soc. China, 2016, vol. 26, pp. 994-1002.

38. S. Meco, G. Pardal, S. Ganguly, R.M. Miranda, L. Quintino, S. Williams: Intern. J. Adv. Manuf. Technol., 2012, vol. 6 https://doi. org/10.1007/s00170-012-4512-6.

39. S. Katatyama: Weld. Int., 2004, vol. 18 (8), pp. 618-25.

40. R. Brockmann, K. Dickmann, C. Radscheit, E. Schubert, and G. Sepold: Weld. Cutt., 2004, vol. 3, pp. E46-E47.

41. J. Ding, F. Li, F. Qu, P. Peyre, and R. Fabbro: Chinese Opt. Lett., 2005, vol. 3 (1), pp. 1-4.

42. M.J. Rathod and M. Kutsuna: Weld. J., 2004, vol. 83, pp. 16-26.

43. M. Kutsuna, H. Ozaki, S. Nakagawa, K. Miyamoto: in Proceedings of the 4th International congress on laser advanced materials processing, Kyoto, 2006.

44. Y. Miyashita, Y. Mutoh, M. Alahori, H. Okumura, I. Nakagawa, and X. Jin-Quan: Weld. Intern., 2005, vol. 19 (6), pp. 687-96.

45. A. Mathieu, R. Shabadi, A. Deschamps, M. Suery, S. Matteï, D. Grevey, and E. Cicala: Opt. Laser Technol., 2007, vol. 39, pp. 652-61.

46. C. Dharmendra, K.P. Rao, J. Wilden, and S. Reich: Mater. Sci. Eng. A, 2011, vol. 528, pp. 1497-1503.

47. M. Alexander, M. Simone, V. Jean-Claude: In Laser materials processing conference. Proceeding of ICA-LEO'05, Miami, 2005, pp. $985-91$.
48. R. Shabadi, M. Suery, and A. Deschamps: Met. Mater. Charact., 2013, vol. 44A, pp. 2672-82.

49. M.J. Zhang, G.Y. Chen, Y. Zhang, and K.R. Wu: Mater. Des., 2013, vol. 45, pp. 24-30.

50. B.Y.M. Roulin, J.W. Luster, G. Karadeniz, and A. Mortensen: Weld. Res., 1999, vol. 78, pp. 151-55.

51. L. Peng, L. Yajiang, W. Juan, and G. Jishi: Mater. Res. Bull., 2003, vol. 38, pp. 1493-99.

52. F. Vollertsen, C. Thomy: in Proceedings ICALEO, Orlando, 2009, pp. 89-97.

53. G.I. Qin, Y.H. Su, and S.J. Wang: Trans. Nonferrous Met. Soc. China, 2014, vol. 24, pp. 989-95.

54. J.L. Song, S.B. Lin, C.L. Yang, G.C. Ma, and H. Liu: Mater. Sci. Eng. A, 2009, vol. 509, pp. 31-40.

55. H. Zhang, J. Liu, and J. Feng: Trans. Nonferrous Met. Soc. China, 2014, vol. 24 (9), pp. 2831-38.

56. G. Zhang, W. Su, J. Zhang, and Z. Wei: Metall. Mater. Trans. A, 2011, vol. 42 (9), pp. 2850-61.

57. C. van der Rest, P. Jacques, and A. Simar: Scr. Mater., 2014, vol. 77 , pp. $25-28$.

58. T. Tanaka, T. Morishige, and T. Hirata: Scr. Mater., 2009, vol. 61, pp. $756-59$.

59. D.R. Andrews: Br. Weld. J., 1962, vol. 79 (7), pp. 650-58.

60. G.A. Bel'Chuk: State of the art of argon-arc welding technology in joining aluminium and aluminium alloys to steel. (Naval Intelligence Support Centre. Washington, DC, 1973).

61. J. Vrenken, C. Goos, T. van der Veldt, W. Braunschweig: Joining in Automotive Engineering, CD-Rom, 2009.

62. J. Yang, Y.L. Li, H. Zhang, W. Guo, and Y. Zhou: Mater. Sci. Eng. A, 2015, vol. 645, pp. 323-27.

63. M.V. Akdeniz and A.O. Mekhrabov: Acta Mater., 1998, vol. 46 (4), pp. 1185-92.

64. P.D. Calderon, D.R. Walmsley, and A. Munir: Weld. J., 1985, vol. 14, pp. 104-12.

65. S. Fukumoto, H. Tsubakino, K. Okita, M. Aritashi, and T. Tomita: Mater. Sci. Technol., 1999, vol. 15, pp. 1080-86.

66. S. Fukumoto, H. Tsubakino, K. Okita, M. Aritoshi, and T. Tomita: Mater. Sci. Technol., 1998, vol. 14, pp. 333-38.

67. G. Kawai, K. Ogawa, H. Hochi, and H. Tokisue: Weld. Intern., 2000, vol. 14 (2), pp. 101-07.

68. B.S. Yilbas, A.Z. Sahin, N. Kahraman, and A.Z. Al-Garni: $J$. Mater. Process. Technol., 1995, vol. 49, pp. 431-43.

69. K. Kimapong and T. Watanabe: Mater. Trans., 2005, vol. 46 (4), pp. 835-41.

70. W.H. Jiang and R. Kovacevic: J. Eng. Manuf., 2004, vol. 218, pp. 1323-31.

71. K. Kimapong and T. Watanabe: Weld. J., 2004, vol. 83, pp. $277-82$

72. Y.C. Chen, T. Komazaki, Y.G. Kim, T. Tsumara, and K. Nakata: Mater. Chem. Phys., 2008, vol. 111, pp. 375-80.

73. R.S. Coelho, A. Kostka, S. Sheikhi, J. Dos Santos, and A.R. Pyzalla: Adv. Eng. Mater., 2008, vol. 10, pp. 961-72.

74. S. Bozzi, A.L. Helbert, T. Baudin, B. Criqui, and J.G. Kerbiguet: Mater. Sci. Eng. A, 2010, vol. 527, pp. 4505-509.

75. H. Springer, A. Kostka, J.F. Dos Santos, and D. Raabe: Mater. Sci. Eng. A, 2011, vol. 528, pp. 4630-42.

76. M. Movahedi, A.H. Kokabi, S.M.S. Reihani, and H. Najafi: Proc. Eng., 2011, vol. 10, pp. 3297-303.

77. S. Kundu, D. Roy, R. Bhola, D. Bhattacharjee, B. Mishra, and S. Chatterjee: Mater. Des., 2013, vol. 50, pp. 370-75.

78. Y. Kusuda: Ind. Robot. Int. J., 2013, vol. 40, pp. 208-12.

79. Z.W. Chen, S. Yazdanian, and G. Littlefair: J. Mater. Sci., 2013, vol. 48, pp. 2624-34.

80. M. Ghosh, R.K. Gupta, and M.M. Husain: Metall. Mater. Trans. A, 2013, vol. 45, pp. 854-63.

81. M. Mohavedi, A.H. Kokabi, S.M.S. Reihani, W.J. Cheng, and C.J. Wang: Mater. Des., 2013, vol. 44, pp. 487-92.

82. X. Liu, S. Lan, and J. Ni: Mater. Des., 2014, vol. 59, pp. 50-62.

83. M. Haghshenas, A. Abdel-Gwad, A.M. Omran, B. Gökçe, S. Sahraemejad, and A.P. Gerlich: Mater. Des., 2014, vol. 55, pp. $442-49$

84. H. Das, R.N. Ghosh, and T.K. Pal: Metall. Mater. Trans. A, 2014, vol. 45, pp. 5098-5106. 
85. H. Das, S.S. Jana, T.K. Pal, and A. De: Sci. Technol. Weld. Join., 2014, vol. 19, pp. 69-75.

86. K.K. Ramachandran, N. Murugan, and S. Shashi-Kumar: Mater. Sci. Eng. A, 2015, vol. 639, pp. 219-33.

87. C.M. Chen and R. Kovacevic: Intern. J. Mach. Tools Manuf., 2004, vol. 44, pp. 1205-14.

88. A. Simar and M.-N. Avettand-Fènoël: Sci. Technol. Weld. Join., 2017, vol. 5, pp. 389-403.

89. M. Girard, B. Huneau, C. Genevois, X. Sauvage, and G. Racineux: Sci. Technol. Weld. Join., 2010, vol. 15, pp. 661-65.

90. J. Tsujino, K. Hidai, A. Hasegawa, R. Kanai, H. Matsuura, K. Matsushima, and T. Ueoka: Ultrasonics, 2002, vol. 40, pp. 371-74.

91. M.S.A. Nehzad and A.H. Ardakani: Mater. Des., 2009, vol. 30, pp. 1103-09.

92. H.D. Manesh and H.S. Shahabi: J. Alloys Compnds., 2009, vol. 476 , pp. $292-99$.

93. H.D. Manesh and A.K. Taheri: J. Alloys Compnds., 2003, vol. 361, pp. 138-43.

94. P. Zhang, Y. Du, S. Xing, L. Zhang, D. Zeng, J. Cui, and L. Ba: J. Mater. Sci. Technol., 2002, vol. 18 (5), pp. 468-70.

95. M.K. Karfoul, G.J. Tatlock, and R.T. Murray: J. Mater. Sci., 2007, vol. 42, pp. 5692-99.

96. H. Springer, A. Kostka, E.J. Payton, D. Raabe, A. Kaysser-Pyzalla, and G. Eggeler: Acta Mater., 2011, vol. 59, pp. $1586-1600$.

97. N. Iwamoto, M. Yoshida, S. Tabata, T. Takeuchi, and M Makino: Trans. Jpn. Weld. Res. Intern., 1975, vol. 4 (2), pp. 171-74.

98. H. Shi, S. Qiao, R. Qiu, X. Zhang, and H. Yu: Mater. Manuf. Process., 2012, vol. 27 (12), pp. 1366-69.

99. J. Luo, W. Chen, and G. Fu: J. Mater. Process. Technol., 2014, vol. 214 , pp. $3002-12$.

100. H. Bang, G. Jeon, I. Oh, and C. Ro: Mater. Des., 2012, vol. 37, pp. $48-55$.

101. M. Merklein and A. Giera: Int. J. Mater. Forum., 2008, vol. 1, pp. 1299-1302.

102. M.-N. Avettand-Fènoël, R. Taillard, G. Ji, and D. Goran: Metall. Mater. Trans. A, 2012, vol. 43, pp. 4655-66.

103. A. Kapil and A. Sharma: J. Clean. Prod., 2015, vol. 100, pp. 35-38.

104. R.M. Miranda, B. Tomas, T.G. Santos, and N. Fernandes: Soldag. Insp. Sao Paulo, 2014, vol. 19 (01), pp. 69-81.

105. T. Aizawa, M. Kashani, and K. Okagawa: Weld. J., 2007, vol. 86, pp. 119-24.

106. V. Psyk, D. Risch, B.L. Kinsey, A.E. Tekkaya, and M. Kleiner: $J$. Mater. Proc. Technol, 2011, vol. 211, pp. 787-829.

107. A.P. Manogaran, P. Manoharan, D. Priem, S. Marya, and G. Racineux: J. Mater. Process. Technol., 2014, vol. 214, pp. 1236-44.

108. A.P. Manogaran, P. Manoharan, D. Priem, S. Marya, G. Racineux: in 6th International Conference on High Speed Forming, 2014, pp. 89-96.

109. H.P. Yu, Z.D. Xu, Z. Fan, Z. Zhao, and C. Li: Mater. Sci. Eng. $A$, 2013, vol. 561, pp. 259-65.

110. J. Li, Q. Yu, Z. Zhang, W. Xu, and X. Sun: Appl. Phys. Lett., 2016, vol. 108, p. 201606.

111. Z. Fan, H. Yu, and C. Li: Scr. Mater., 2016, vol. 110, pp. 14-18.

112. H.P. Yu, Z.D. Xu, H.W. Jiang, Z.X. Zhao, and C.F. Li: Trans. Nonferrous Met. Soc. China, 2012, vol. 22, pp. s548-52.

113. H. Yu, Z. Fan, and C. Li: J. Mater. Proc. Technol., 2014, vol. 214, pp. 141-50.

114. J.-Y. Shim, I.-S. Kim, M.J. Kang, I.J. Kim, K.J. Lee, and B.Y. Kang: Mater. Trans., 2011, vol. 52 (5), pp. 999-1002.

115. Z. Fan, H. Yu, and C. Li: J. Mater. Process. Technol., 2016, vol. 229 , pp. $230-43$

116. A. Ben-Artzy, A. Stern, N. Frage, V. Shribman, and O. Sadot: Intern. J. Impact Eng., 2010, vol. 37, pp. 397-404.

117. A. Lorenz, J. Lueg-Althoff, G. Göbel, C. Weddeling, E. Beyer, A.E. Tekkaya: in 6th International Conference on High Speed Forming, 2014, pp. 189-98.

118. I. Oliveira, P. Teixeira, A. Reis: in 6th International Conference on High Speed Forming, 2014, pp. 117-26.

119. J. Cui, G. Sun, J. Xu, Z. Xu, X. Huang, and G. Li: J. Mater. Process. Technol., 2016, vol. 227, pp. 138-46.
120. K.-J. Lee, S. Kumai, T. Arai, and T. Aizawa: Mater. Sci. Eng. A, 2007, vol. 471, pp. 95-101.

121. M. Geyer, A. Rebensdorf, S. Böhm: in 6th International Conference on High Speed Forming, 2014, vol. 51-60.

122. S.D. Kore, P.P. Date, and S.V. Kulkarni: J. Mater. Process. Technol., 2008, vol. 208, pp. 486-93.

123. Y. Zhang, S.S. Babu, C. Prothe, M. Blakely, J. Kwasegroch, M. LaHa, and G.S. Daehn: J. Mater. Process. Technol., 2011, vol. 211, pp. 944-52.

124. T. Blazynski: Explosive Welding, Forming and Compaction, Springer, Dordrecht, 2012.

125. K. Mori, N. Bay, L. Fratini, F. Micari, and A.E. Tekkaya: CIRP Ann. Manuf. Technol., 2013, vol. 62 (2), pp. 673-94.

126. J. Verstraete, W. De Waele, and K. Faes: Sustain. Constr. Design., 2011, vol. 2 (3), pp. 458-64.

127. EM THEORY MANUAL Electromagnetism and Linear Algebra in LS-DYNA, 2012

128. H.O.S. Eide, E.A. Melby: Blast Loaded Aluminum Plates Experiments and numerical simulation, Norwegian University of Science and Technology, 2013.

129. A.P. Manogaran: "Développement de procédé de soudage par point par impulsion électromagnétique-Assemblage hétérogène $\mathrm{Al} / \mathrm{Fe}, " \mathrm{PhD}$, Ecole Centrale de Nantes, Nantes, 2013.

130. M. Leroy, J. Renaud: Formage électrohydraulique, Tech. l'ingénieur. Génie mécanique, 1980.

131. P. Deshayes, R. Taillard, C. Perdrix, E. Amoris: in 6th International Rolling Conference, Dusseldorf, VDEh, 1994, pp. 205-12.

132. A.R. Marder: Prog. Mater. Sci., 2000, vol. 45 (3), pp. 191-271.

133. M. Watanabe, S. Kumai, and T. Aizawa: Mater. Sci. Forum, 2006, vols. 519-521, pp. 1145-50.

134. A. Anghelus, M.-N. Avettand-Fènoël, C. Cordier, and R. Taillard: J. All. Cpnds., 2015, vol. 631, pp. 209-18.

135. T. Sapanathan, R.N. Raoelison, E. Padayodi, N. Buiron, and M. Rachik: Mater. Des., 2016, vol. 102, pp. 303-12.

136. M. Watanabe, S. Kumai, G. Hagimoto, Q. Zhang, and K. Nakayama: Mater. Trans., 2009, vol. 50 (6), pp. 127985.

137. P. Matysik, S. Jozwiak, and T. Czujko: Mater., 2015, vol. 8, pp. 914-31.

138. R. Pretorius, T.K. Marais, and C.C. Theron: Mater. Sci. Eng., 1993, vol. 10, pp. 1-83.

139. C.C. Theron, O.M. Ndwandwe, J.C. Lombaard, and R. Pretorius: Mater. Chem. Phys., 1996, vol. 46, pp. 238-47.

140. M. Kajihara: Acta Mater., 2004, vol. 52, pp. 1193-1200.

141. V. Shribman: Magnetic pulse welding for dissimilar and similar materials, in Proceedings 3rd International Conference on High Speed Forming, Dortmund, 2008, pp. 13-22.

142. K. Masaki, Y.S. Sato, M. Maeda, and H. Kokawa: Scr. Mater., 2008, vol. 58, pp. 355-60.

143. M. Militzer, W.P. Sun, and J.J. Jonas: Acta Metall. Mater., 1994, vol. 42, pp. 133-41.

144. S.H. Carpenter:Explosion welding: a review in Shock waves and high strain rate phenomena in metals in Concepts and Applications, M.A. Meyers and L.E. Murr, eds., Plenum press, New York, 1981, pp. 941-59.

145. M.P. Bondar and V.M. Ogolikhin: J. Phys., 1985, vol. 46 (5), pp. $379-84$

146. S. Cui, Y. Du, L. Zhang, Y. Liu, and H. Xu: Calphad, 2010, vol. 34 , pp. $446-51$.

147. A. Vivek, S.R. Hansen, B.C. Liu, and Glenn.S. Daehn: J. Mater. Process. Technol., 2013, vol. 213, pp. 2304-11.

148. S.H. Xia, J. Wang, J.T. Wang, and J.Q. Liu: Mater. Sci. Eng. A, 2008, vol. 493 (1-2), pp. 111-15.

149. S.K. Singh, K. Chattopadhyay, G. Phanikumar, and P. Dutta: Acta Mater., 2014, vol. 73, pp. 177-85.

150. L. Fu, L.Y. Duan, and S.G. Du: Weld. Res., 2003, vol. 19, pp. $65-70$.

151. R.S. Mishra and Z.Y. Ma: Mater. Sci. Eng. R, 2005, vol. 50, pp. $1-78$

152. R. Nandan, T. DebRoy, and H.K.D.H. Bhadeshia: Prog. Mater. Sci., 2008, vol. 53, pp. 980-1023. 
153. A. Arora, Z. Zhang, A. De, and T. DebRoy: Scr. Mater., 2009, vol. 61, pp. 863-66.

154. G. Buffa, J. Hua, R. Shivpuri, and L. Fratini: Mater. Sci. Eng. A, 2006, vol. 419, pp. 381-88.

155. K.V. Jata and S.L. Semiatin: Scr. Mater., 2000, vol. 43, pp. 743 49.

156. Ø. Frigaard, Ø. Grong, and O.T. Midling: Metall. Mater. Trans. A, 2001, vol. 32, pp. 1189-1200.

157. A. Gerlich, G. Avramovic-Cingara, and T.H. North: Metall. Mater. Trans. A, 2006, vol. 37, pp. 277386.
158. P. Heurtier, C. Desrayaud, and F. Montheillet: Mater. Sci. Forum, 2002, vols. 396-402, pp. 1537-42.

159. H. Schmidt and J. Hattel: Simul. Mater. Sci. Eng. A, 2005, vol. 13 , pp. 77-93.

160. G. Buffa, J. Hua, R. Shivpuri, and L. Fratini: Mater. Sci. Eng. A, 2006, vol. 419, pp. 389-96.

161. Friction Stir Welding and Processing, 7th ed., R.S. Mishra, and M.W. Murray, eds., Friction Stir Welding and Processing, ASM international, Novelty, 2007.

162. T. Sapanathan, R.N. Raoelison, N. Buiron, and M. Rachik: Scr. Mater., 2017, vol. 128, pp. 10-13. 